University of Rhode Island

DigitalCommons@URI

Open Access Master's Theses

1990

\title{
Socially Responsive Management: Reforming the Forest Service from Within
}

Karen L. Sherman

University of Rhode Island

Follow this and additional works at: https://digitalcommons.uri.edu/theses

\section{Recommended Citation}

Sherman, Karen L., "Socially Responsive Management: Reforming the Forest Service from Within" (1990). Open Access Master's Theses. Paper 702.

https://digitalcommons.uri.edu/theses/702

This Thesis is brought to you for free and open access by DigitalCommons@URI. It has been accepted for inclusion in Open Access Master's Theses by an authorized administrator of DigitalCommons@URI. For more information, please contact digitalcommons@etal.uri.edu. 
SOCIALLY RESPONSIVE MANAGEMENT:

REFORMING THE FOREST SERVICE FROM WITHIN

BY

KAREN L. SHERMAN

A RESEARCH PROJECT SUBMITTED IN

PARTIAL FULFILLMENT OF THE REQUIREMENTS

FOR THE DEGREE OF MASTER OF COMMUNITY PLANNING

UNIVERSITY OF RHODE ISLAND

1990 


\title{
MASTER OF COMMUNITY PLANNING
}

\author{
RESEARCH PROJECT OF \\ KAREN L. SHERMAN
}

APPROVED:

Major Professor

ACKNOWLEDGED:

Director

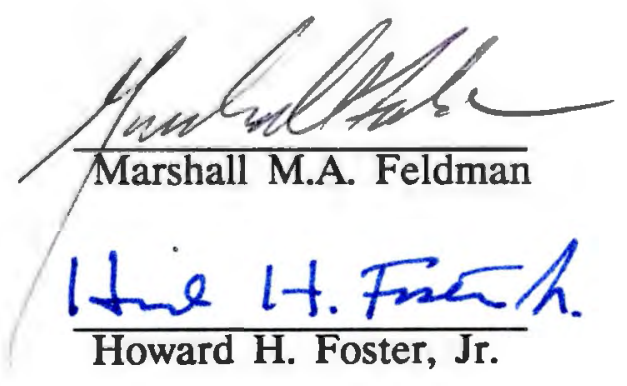




\section{ACKNOWLEDGEMENTS}

"These beautiful days must enrich all my life. They do not exist as mere pictures...but they saturate themselves into every part of the body and live always." - John Muir

Many thanks to CPAD folks and the staff of the Shoshone National Forest for their support and direction in the development and completion of this research project. Special thanks to Mom and Dad, my pillars - Michael Phillips, Terry Whalen, Diane Feather, and Jon Stevens, and to Dr. Marshall Feldman for making me think twice. 


\section{TABLE OF CONTENTS}

ACKNOWLEDGEMENTS .................... ii.

LIST OF FIGURES $\ldots \ldots \ldots \ldots \ldots \ldots \ldots \ldots \ldots$

LIST OF TABLES $\ldots \ldots \ldots \ldots \ldots \ldots \ldots \ldots \ldots \ldots$

Chapters

I INTRODUCTION .......................... 1-1

II FOREST SERVICE PLANNING PROCESS . . . . . . . . . . . . . . . . . . . . . . . .

2.1 Legislative Mandates ................... 2-2

2.2 Jurisprudence . . . . . . . . . . . . . . . . . . . 2-8

2.3 Forest Plan Monitoring Requirements ............. 2-. 2-9

2.4 Plan Development ................... 2- 2-10

2.5 Management Situation - Shoshone National Forest ..... 2-11

2.6 Greater Yellowstone Area ............... 2-15

III SOCIALLY RESPONSIVE MANAGEMENT FRAMEWORK . . . . 3-1

3.1 Human Resource Units .................. 3-5

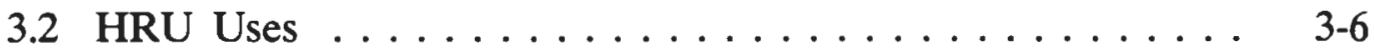

3.3 Defining Cultural Descriptors Utilized ........... 3-8

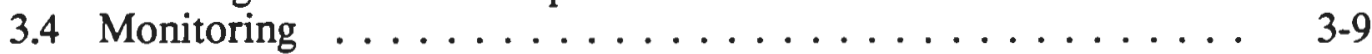

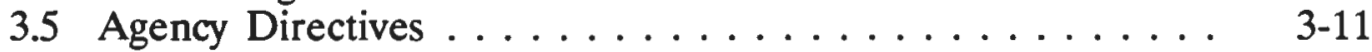

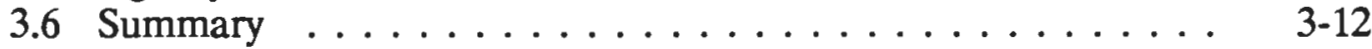

IV PUBLIC PARTICIPATION AND SOCIAL

IMPACT ASSESSMENT . . . . . . . . . . . . . . . . . . . . . . . . . .

4.2 Social Impact Assessment .................. 4-2

4.3 Summary ........................ 4 4

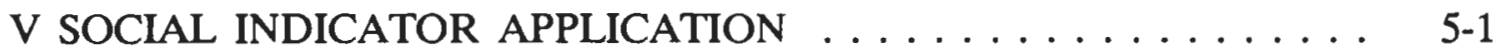

5.1 Social Indicators: Definitions ............... 5-3

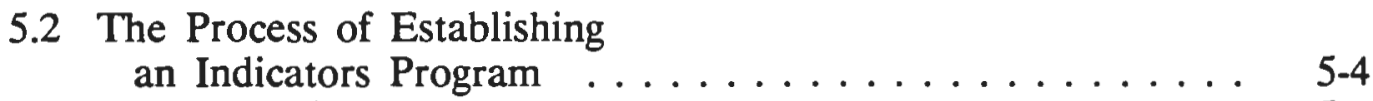

5.3 Problems with Indicator Development . . . . . . . . . 5-6

5.4 Application of Forest Service Social Impact Analysis . . . . . 5-7

5.5 Social Indicators Implicit in the Forest Service's Implementation of SRM .................... 5-11 
Chapters

VI EVALUATION OF HRUs $\ldots \ldots \ldots \ldots \ldots \ldots \ldots$. $\ldots \ldots \ldots \ldots$

6.1 Evaluation $\ldots \ldots \ldots \ldots \ldots \ldots \ldots \ldots \ldots \ldots \ldots$ 6-2

6.2 Evaluation from Forest Documentation ......... 6-17

VII RECOMMENDATIONS AND CONCLUSIONS $\ldots \ldots \ldots \ldots$ 7-1

\section{APPENDICES}

Appendix A Environmental Analysis, Documentation, and Implementation Overview . . . . . . . . . . A-1

Appendix B Socially Responsive Management Program

Application . . . . . . . . . . . . B

Appendix C Human Resource Unit Example ............ C-1

Appendix D Data Sources for Social Impact Analysis ..... D

Appendix E HRU Design and Sources ........... E-1

BIBLIOGRAPHY 


\section{LIST OF FIGURES}

Figure 2.1 .- Shoshone National Forest Planning Area . . . . . . . . . 2-14

\section{LIST OF TABLES}

Table 2.1 .- Planning Problems Statements . . . . . . . . . . . . . 2-13

Table 3.1 -- Typical Sources of Publics . . . . . . . . . . . . . 3-11

Table 6.1 - HRU evaluation . . . . . . . . . . . . . . 6-17 


\title{
CHAPTER 1 INTRODUCTION
}

\begin{abstract}
"...suppose that a major cause of environmental destruction is ignorance about what is likely to happen and what less harmful alternatives may exist. Then it is worth considering how we might fit more extensive "human" environmental analysis within the pluralism and incrementalism of American politics." - Taylor, 1984
\end{abstract}

Federal land management agencies have been mandated by administrative reform legislation to plan for the future management and use of public lands, to address public concerns and demands, and to preserve and protect the natural resources on those lands (USDA Forest Service, 1988). Broad discretion is given to the Forest Service under the concept of "multipleuse management", for legislative guidance is vague on the key questions of how priorities are to be assigned when uses conflict (Taylor, 1984). Because there is a continuum of philosophical positions on natural resources which extends from pure human consumptive use to biosphere maintenance, the reality of public land management is that some uses conflict (Culhane, 1981).

Because human variables do not generally fit well, if at all, into the established analytic schemes of those who study non-human environmental variables, the Socially Responsive Management (SRM) system was developed for the Rocky Mountain Region (Region 2) of the US Forest Service. SRM was designed to increase organizational effectiveness in working with the public and responding to their interests in resource decision-making. 
Human Resource Units (HRUs) are the basic socioeconomic documents that result from organizational implementation of SRM. Human Resource Units are delineated as local geographic areas characterized by particular patterns of cultural lifestyles, economic conditions, institutional arrangements and topography. Optimally, they are used to "design, implement and monitor management actions that respond to changing social and economic conditions at the local level (Greiwe, 1980)." However, it is not clear whether these units are analysis units or simply a data base of statistical and background information on local communities, forest users and interest groups.

There is little evidence that HRUs are used for anything more than meeting administrative requirements for social impact assessments. This Masters Research Project will use the Shoshone National Forest as a case study to determine how HRUs are used and how they could be better used in the planning process (e.g. monitoring, issue development, public participation). Two questions will be addressed: 1. What are the potential uses of basic socioeconomic analysis units to the Forest Service field personnel and administrators and 2. What are the proposed modifications to the Unit's use, development, and applications as a result of this analysis?

Section I consists of chapters that discuss the agency's Socially Responsive Management program framework. Chapter 2 provides background on the agency planning process, goals and mandates. It describes the legal background and mandates that guide the Forest Service planning process. The National Forest Management Act of 1976 and the National Environmental 
Policy Act of 1970 are the primary statutes that guide agency planning and public participation actions. The chapter also briefly presents the Forest's management situation, its geography and relationship with local communities.Chapter 3 briefly defines the Human Resource Unit as prescribed by the Foundation for Urban and Neighborhood Development and outlines uses and program monitoring and describes the SRM program philosophy, its objectives and program applications. Chapter 4 details development and application of public participation and Social Impact Analysis. Internal directives and guidelines are summarized. Chapter 5 is an application of social indicators to the HRU framework. Definitions, criteria and limitations are also discussed.

Section II consists of chapters of a case study evaluation, focussing on the Shoshone National Forest. Chapter 6 consists of an evaluation of HRUs, with emphasis on information development through application of agency guidelines and the Socially Responsive Management "philosophy". This evaluation is not comprehensive, rather the questions addressed and the examples used aid in the development of viable recommendations for program restructuring. The seventh and final chapter is a series of recommendations for the use and development of HRU's on the Shoshone National Forest. Cooperative efforts, monitoring, and dual qualitative-quantitative information systems are emphasized.

The primary methodology used for this project was a review of the SRM and forest planning guidelines for social assessment. Additionally, data sources, 
agencies, key informants, and background information were researched for HRU development. Extensive use was also made of the Shoshone National Forest's Planning records, files and public documentation.

This project is a general study of the application of the Socially Responsive Management program to a multiple-use federal agency. It is an attempt to disclose aspects of program application through public participation, Social Impact Assessment, and social indicator applications and focusses on program documentation in the form of Human Resource Units.

Recommendations for HRU use and development should aid in the Forest's current Plan amendment process. 


\section{CHAPTER 2 \\ THE FOREST SERVICE PLANNING PROCESS}

The National Forest Service is in the midst of its most ambitious administrative undertaking: developing, updating, and amending comprehensive plans for America's 155 national forests (Benfield, 1987). There are numerous legislative mandates for management of National Forest System lands. Collectively, the legislation constitutes an ambitious attempt at long-term planning for the sustained productivity of valuable natural resources (Shands, 1986).

More specifically, the formal Forest Service land management planning process is defined by: 1 . legislation that interprets and codifies the original intent of the Forest and Rangeland Renewable Resource Planning Act of 1974 (RPA), 2. regulations that transform the original intent defined in the legislation into steps for developing, adopting and revising plans, and 3. internal guidelines and directives that further clarify the intent and regulations to facilitate plan development (Forest Service Handbook and Manual).

Several levels of internal agency guidance exist in plan development. These are: National Forest system-wide goals based on the RPA program and nine regional guides which are further allocated to the individual forests on the basis of their individual resource capabilities in their Forest Plans. Forest Plans provide an analysis that is nearly site specific. The objective of forest planning's "scientific conservation" is to blend local, regional and national needs with the 
multiple-use production capabilities of a forest to choose a course of action that will maximize net public benefits (Mitchell, 1988).

All Forest Service actions occur under the guise of three principles: (1) care for the land and serve the public, (2) provide for multiple use, sustained yield production of goods and services that maximize net public benefit while maintaining the viability of the involved natural system, and (3) manage the national forests to provide the greatest good for the greatest number in the long run (net public benefits). Net public benefits is an expression used to signify the long-term value to the nation of all outputs and effects (benefits) less all associated inputs and negative effects (costs) whether they can be quantitatively valued or not [36 Code of Federal Regulations (CFR) Chapter II, Part 209.1].

\subsection{Legislative Mandates}

Numerous laws directly influence the Forest Service planning process. The most significant of these are:

1. National Forest Management Act of 1976

The Renewable Resources Planning Act of 1974 (RPA) as amended by the National Forest Management Planning Act (NFMA) can be looked on as the culmination of a process of changing the congressional directives to the Forest Service from those consistent with an initial custodial role to those of an 
intensive management role in the administration of the National Forests (Krutilla and Haigh, 1978). RPA and NFMA established a process for developing an overall renewable resources policy for the nation and represented an attempt to establish a long-term planning process for the nation's public and private forest lands in accordance with the Multiple-Use Sustained Yield Act of 1960 (Wilderness Society, 1983). NFMA requires 10-year plans for each of the 123 administrative units for the 154 national forests. The NFMA planning regulations (36 CFR 219) state that plans will be based on a systematic interdisciplinary approach, early and frequent public participation, and responsiveness to changing conditions in the land and changing social and economic demands of the American people.

Plans guide all natural resource management activities and establish management standards and guidelines for the National Forest System. They determine resource management practices, levels of resource production and management, and the availability and suitability of lands for resource management (36 CFR Chapter II, Part 219.1, 1986).

In at least ten separate provisions of the NFMA, Congress directed the Forest Service to provide the public a voice in the planning of the national forests (Wilderness Society, 1983). As a general mandate, Section 14 provides that "the Secretary (of Agriculture), by regulation, shall establish procedures, including public hearings where appropriate, to give the Federal, State and local governments and the public adequate notice and opportunity to comment on the formulation of standards, criteria and guidelines applicable to Forest 
Service programs" (90 Stat. 2949). Other public involvement in the planning process comes through workshops, meetings, conferences, written responses on issues, and commentary on the Draft EIS (DEIS) and the draft Forest Plan. Plan amendments and periodic revisions of land management plans are also to be carried out with public participation.

The Act's public participation provisions also allow for administrative input which may prove more accessible and more prophylactic than litigation. To the extent that policy can reflect the will of the nations' citizens, participation in drafting individual land management plans is probably the best way for the agency to be future-oriented and apply that "public will". Local residents are the most likely participants in the process because they represent a relatively finite group, and they have the most at risk.

In a sense, the public participation provisions of the 1976 Act represent total reversal of National Forest policy (Mulhern, 1978). The system of National Forests was originally established to save forests from the timber industry which was buying and cutting over Federally-owned lands at a rapid rate. The Forest Service has historically been dedicated to conservation and has been relatively free of intervention from the Department of Agriculture and the public. With the addition of the outside participation requirements of both the National Environmental Policy Act of 1969 and NFMA, it is not just the Forest Service, but the public as well that now stand between use and abuse of the National Forests. 


\section{National Environmental Policy Act of 1969}

The National Environmental Policy Act (NEPA) requires that policies, regulations and public laws are interpreted and administered in accordance with NEPA procedures, that is, by systematic interdisciplinary approaches to environmental planning and evaluation (40 CFR 1500-1508, 1978). Agencies are required to integrate the NEPA process with other planning at the earliest possible time to insure that planning and decisions reflect environmental values, to avoid delays later in the process, and to head off potential conflicts. NEPA's directives are primarily concerned less with the result of forest planning than with its form and procedure.

Particularly critical to forest planning is Section $102(2)(C)$ of NEPA, which requires for any "major Federal action significantly affecting the quality of the human environment" a detailed statement describing the impacts of the action and the alternatives to it. Consequently, Forest Service regulations now require an EIS for each National Forest plan. Appendix $\mathbf{A}$ is a schematic environmental analysis, documentation, and implementation overview under NEPA.

NEPA is, in a sense, an attempt to change the intelligence capabilities of the federal agencies, the kind of information they routinely develop and the weight they routinely give it in their decisions by substituting analysis for reorganization and providing formal public analysis of environmental impacts (Taylor, 1984). Thus NEPA reinforces the Forest Service's duty under the Administrative Procedures Act (APA) to develop information on which to base 
Forest Plans. The process is a seemingly open and accountable exercise, since it is largely intended to facilitate participation in and scrutiny of agency affairs by interested outside parties. The Environmental Policy Procedures Handbook, in fact, constitutes a sizable portion of the Forest Service Handbook as amended. Additionally, Forest Service guidelines for implementing NEPA include provisions to reduce EIS paperwork by establishing page limits on documents and "tiering" documents to each other by reference (e.g most project Environmental Impact Statements would be tiered to the Forest Plan). The NEPA statutory requirement for breadth in forest planning alternatives is reinforced by the Forest Service's planning regulations. Specifically, the agency must examine "a broad range of alternatives" that reflect, to the extent practicable, "the full range of major commodity and environmental resource uses and values" (Mulhern, 1978). Moreover, the alternatives must present different ways of responding to "major public issues" as well as to management concerns and opportunities identified in the planning process; NEPA discloses an exchange between administrative political and social knowledge and technical knowledge. Not only must data specifically relied on by the Forest Service in adopting and upholding a forest plan be adequate and available, but also the agency must make a good faith effort to develop the information necessary to resolve key issues (Benfield, 1987). 


\section{Multiple Use-Sustained Yield Act of 1960}

This Act states that no resource would be given statutory priority over the others; due consideration is given to the relative values of the various resources in "joint production" - outdoor recreation, timber, wildlife, range, and watersheds.

\section{Wilderness Act of 1964}

This Act provides for the establishment and administration of the National Wilderness Preservation System, which is to be administered for the use and enjoyment of the American people in such a manner as will leave the system unimpaired for future use and enjoyment as wilderness.

\section{Wild and Scenic Rivers Act of 1968}

This Act provides for designation of rivers as "Wild and Scenic" and preserves portions of designated rivers from development. Management of rivers within the System is directed toward preserving the scenic, recreational, geologic, historic, or other value that justified its conclusion in the System (USDA Forest Service, 1986).

\section{The Endangered Species Act of 1973}

This Act requires "federal agencies to consult with the US Fish and Wildlife Service in order to insure that actions that they authorize, fund, or carry out do not jeopardize the continued existence of an endangered or 
threatened species or result in the adverse modification or destruction of their critical habitat" (P.L. 93-205).

\subsection{Jurisprudence}

Wilkinson (1987) recognizes that the field of comprehensive forest planning is a fascinating study in jurisprudence. He continues by stating that the United States' system of laws does not normally address issues with such a high degree of complexity (hundreds of millions of acres and millions of users), diverse expertise (both administrative and cross-disciplinary) and extremely longterm impacts (a key part of forest law and policy rests on silvicultural, economic, and biological conditions generations hence). Furthermore, forest planning "germinates" in a heavily interdisciplinary context, forest law tends to be complex, the Forest Service is dominated by the "forester personality", and forest planning involves traditional "bread and butter" socioeconomic issues. 


\subsection{Forest Plan Monitoring Requirements}

Plans tell what environmental, economic, and social indicators are to be monitored. The results of monitoring indicate how well objectives have been met and how closely management standards have been applied. ${ }^{1}$ Monitoring of the forest plan is conducted with regard to three aspects: implementation, effectiveness, and validation.

1. Implementation. Implementation monitoring determines if plans, prescriptions, projects, and activities are implemented as designed and in compliance with forest plan management direction, objectives, and standards and guidelines.

2. Effectiveness. Effectiveness monitoring determines if plans, prescriptions, projects, and activities are effective in meeting management direction, objectives, and the standards and guidelines.

3. Validation. This type of monitoring is designed to ascertain whether the initial assumptions and coefficients used in development of the forest plan are correct or if there is a better way to meet forest planning regulations, policies, goals, and objectives. Validation monitoring may be used to recommend

\footnotetext{
${ }^{1}$ The wilderness Society contends that to be effective, citizens should maintain periodic involvement in monitoring over the ten to fifteen year life of the Forest Plan.
} 
implementation. And, it may be used to ensure that planned mitigation actions are implemented and maintained as designed; cumulative effects of project implementation should not exceed standards or thresholds stated in the forest plan.

\subsection{Plan Development}

The Wilderness Society (1983) and the USDA Forest Service (1988b) offer the following summary nine steps in the development of a Forest Plan. These are:

1. Identification of issues and concerns.

2. Development of evaluation criteria (to guide selection of alternatives).

3. Inventory resource values and perform special studies.

4. Analyze the management situation and the Forest's potentials for resource production.

5. Formulate alternatives and determine and compare their physical, biological, social and economic impacts. There is also a comparison of how each alternative relates to the objectives of the national level RPA program.

6. Evaluate alternatives in a draft Environmental Impact Statement (EIS).

7. Select the "chosen alternative" and attain plan approval by the Regional Forester.

8. Complete monitoring. 


\subsection{Management Situation - Shoshone National Forest}

The Shoshone National Forest is presently in the process of updating and amending its Land and Resource Management Plan. Forest management actions include a wide-spectrum of activities and resources from Wilderness preservation to road-building. In the initial phase of the planning process, issues and concerns are being identified through a review of past public involvement efforts and through contact with networks identified in Forest Human Resource Units (HRUs) and by District Rangers. When the review is complete, federal, state and local agencies and the public will be asked to comment on the issues identified in this phase of the planning process. These public issues and management concerns, expressed in planning problem statements, will ultimately determine the scope of the EIS. Examples are noted in Table 2.1. 
* Balanced Timber Management for Multiple Resource Needs

* Adequate Variety, Amount, dispersion, and Quality of Recreation Opportunities

* Adequate Level and Kind of Livestock Grazing

* Manage wilderness to Best Satisfy Legal Requirements and Public Needs

* Adequate Level of Road and Trail System Development and Maintenance

* Manage Threatened and Endangered Species Habitat to Achieve Recovered Populations

* Appropriate Level of Rights-of-Way Acquisition, Land Adjustments and Special Uses

* Ensure That Management Plans of All the Different Agencies in the Greater Yellowstone Area are Coordinated

* Adequate Funding and Completion of Monitoring

The Shoshone National Forest is located in the northwest corner of Wyoming. The Forest encompasses a gross area of 2,466,097 acres of which $2,433,125$ acres are public lands administered by the Forest Service. The remaining 32,972 acres are in private ownership or are under the jurisdiction of the State of Wyoming. The Forest is divided into five subunits: Clarks Fork, Wapiti, Greybull, Lander and Wind River Ranger Districts in two Wyoming counties - Park and Fremont. Figure 2.1 is a map of the Forest's planning area. 
As an indication of multiple-use on the Forest, budgets are broken down into 13 line items. These are: general administration, trails, roads, protection, facilities, lands, minerals, soil and water, timber, range, wildlife, recreation, and land management planning. In addition a number of special uses occur. These include water transmission, rights-of-way, commercial operations on forest land, seasonal cabins, etc.

The Shoshone provides access to the east and northeast entrances to Yellowstone National Park (the Park). The Forest sustains camping facilities as well as lodges and resorts which are used by visitors to the Park and Forest. The majority of Forest land that borders the Park is Congressionally-designated Wilderness. In fact, $57 \%$ of the Forest is Wilderness and will remain so with the mandates of the Wyoming Wilderness Act of 1984. Other areas have been designated as special areas on the Forest. These include the Dunoir Special Management Area and the Beartooth High Lakes Study Area. 


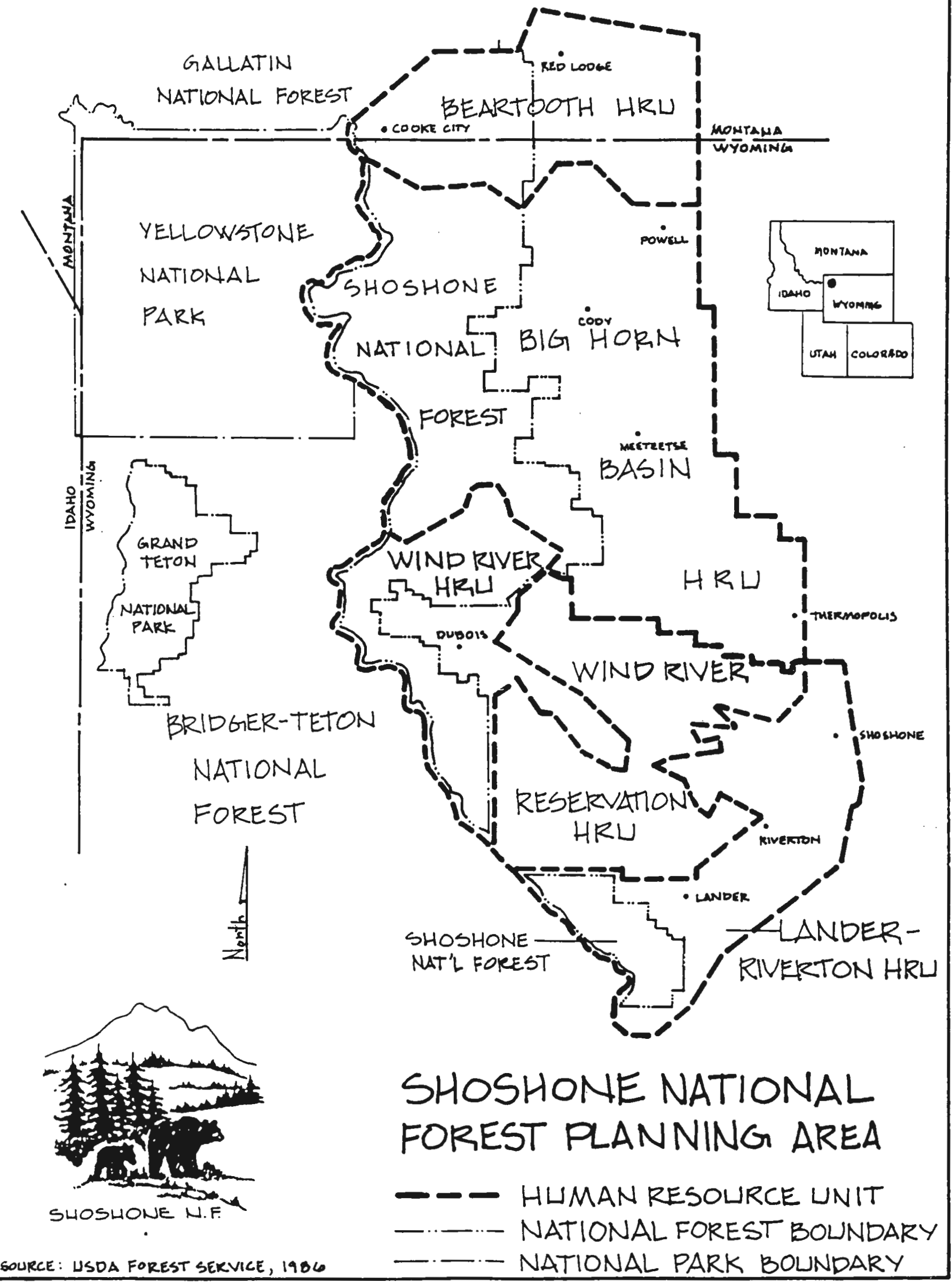




\subsection{Greater Yellowstone Area}

More than 3.5 million people visit the Greater Yellowstone Area (GYA) each year. The GYA is one of the largest essentially intact natural areas located in the temperate zones of the earth. The area is world renowned for its scenery, wildlife, wilderness, outdoor recreational opportunities, and geologic and thermal features.With over 19 million acres, the area is massive. It is also politically and administratively complex, encompassing two national parks, six national forests, three federal wildlife refuges, five "gateway" towns, thirteen counties, and portions of three states (Baden and Leal, 1990).

Concerns have been expressed by some segments of the public that National Park and National Forest management in the GYA is not as wellcoordinated as it should be. Some people fear that direction in management plans for the Park Service and the Forest Service do not take into account the cumulative effects of activities on the unique natural resources. Other are concerned that because of the differing management objectives of the agencies, some important aspects of the area as a whole may suffer irreparable damage or that restrictions upon multiple-uses may harm the livelihoods of local people (Chase, 1986; McNamee, 1987; Reynolds, 1987; Baden and Leal, 1990). 


\section{CHAPTER 3 \\ SOCLALLY RESPONSIVE MANAGEMENT FRAMEWORK}

In 1980, there was no Forest Service Manual direction for local offices to meet the requirements of the National Environmental Policy Act (NEPA) and the National Forest Management Act (NFMA) for social assessment in forest plan development. ${ }^{1}$ In response to these requirements, Region 2 adopted Socially Responsive Management (SRM). SRM was meant as a framework for the analyses to be completed under the requirements of NEPA and NFMA. Region 2 does not, however, have an SRM coordinator and implementation of the SRM "philosophy" has varied throughout the Region.

Socially Responsive Management (SRM) is a management system developed by the Foundation for Urban and Neighborhood Development (FUND) in Denver and designed to increase individual and organizational effectiveness in working with the public and responding to its interests in resource decision-making. The intent of SRM was to institute a process for monitoring people's changing resource use, activities, and attitudes.

SRM is based on the philosophy of managing resources with people rather than for people. It is an approach for arriving at decisions responsive to the public as well as to organizational objectives. Responsive management means not to disavow mandated objectives but to consciously reflect on how they are continuously interpreted in practice (Shannon, 1986).

'The Rocky Mountain Region includes most Forests in wyoming and the northwest quarter of Colorado. 
SRM is designed to insure agency responsiveness to "changing social and economic demands of the American people" through social analysis (Tremaine, 1981). SRM offers a framework that guides an ongoing, systematic collection and monitoring of information for the purpose of being aware and responsive to the surrounding social environment if implemented systematically. This suggested framework is illustrated in Appendix B.

As an approach to management, SRM emphasizes attaining and maintaining sensitivity to and awareness of public needs and demands on the National Forests, changing social conditions, and the issues generated by the public having to do with use and management of the National Forests (Griewe, 1980). FUND defined the objectives of SRM as being: 1. to make employees aware of the social conditions that surround them, 2. to improve communication between the agency and the public, 3. to enhance public understanding and participation in the decision-making process, 4. to insure consideration of social impacts of proposed management actions within the context of the unique social conditions of surrounding communities, and 5. to provide an issue identification and monitoring process for use in daily management and long-range planning.

According to its architects, SRM provides "practical tools" for describing the characteristics of people and their environment, especially elements relating to the management of natural resources. The information assembled by social analysis units and documents point out the unique social and economic considerations that should be factored into the land management process. 
Griewe further states that Social Resource Management procedures encourage the application of an analysis unit delineated by "people" boundaries rather than political boundaries such as county and state jurisdictional lines. In addition to collecting information about the local publics associated with resource management activities, regional and national publics should be identified; the cultural descriptors are also applied to characterize influences on resource management originating from outside a particular geographic area.

As applied to Forest Service Planning, SRM has two foci: social impact assessment (SIA) and public participation. These are briefly outlined here. A more extensive discussion is given in the Chapter 4.

\section{A. Social Impact Assessment}

Information on the social considerations involved in resource management is essential to making sound decisions. In daily operations, an awareness of the social environment assists a manager to reach decisions that resolve public issues rather than create new ones. In long-range planning, knowledge of social trends is needed to design viable future resource programs. In the preparation of an environmental impact statement, identification of social conditions affected by a proposed project is required to manage the impacts of resource development.

Griewe (1979) defines Social Impact Analysis (SIA) as being "systematic procedures for determining the social impacts associated with specific resource decisions, programs and policies". SIA is used to appraise the effects of 
proposed management actions on social conditions and public issues identified in a given geographic area. The end product is a social impact assessment which establishes a framework for managing impacts and implementing desired mitigation measures. SRM can be used to describe the effected environment, to establish baseline conditions, and to estimate effects of alternatives.

\section{B. Public Participation}

Each "public" communicates its resource-related interests in different ways. According to Griewe (1980), some belong to clubs and associations to represent their interests, attend public meetings, or are skilled at expressing their views in other formal ways. Still others do not get involved, if ever, until their interests are directly impacted, which is usually after a decision has been made.

SRM optimally helps managers know what contact with the public is necessary before making a decision. This is accomplished by tapping into the

networks people use to communicate and protect their interests (Griewe, 1980). The network approach is an effective way to involve those who do not conventionally participate in an organization's scheduled meetings.

Public participation requires a balancing of views among persons, on a somewhat vague but essentially one-person-one-vote basis (Clawson, 1983). Resource managers must find ways to enlist the interest and the participation of as many user groups as possible from the very beginning o the process, to carry their interests throughout, and to fully inform them as to the final result. 


\subsection{Human Resource Units}

Human Resource Units (HRUs) are the base geographic units of social analysis used by the Rocky Mountain Region in implementation of SRM. Appendix $\mathrm{C}$ is an example Human Resource Unit from the Big Horn National Forest in north-central Wyoming. An HRU is defined as a local geographic area characterized by particular patterns of cultural lifestyles, economic conditions, institutional arrangements, and topography. Because of this, "they provide a means to organize data concerning the social environment of the Forest" (USDA Forest Service, 1986). They are used optimally to "design, implement and evaluate management actions that respond to changing social conditions or natural resource uses at the local level" (Griewe, 1981). Field information about the social resources involved in natural resource management can be used to make better day-to-day decisions, provide input to long-range and project planning, and shape the requirements of formal social impact analysis effort.

Generally, a selected set of "cultural descriptors" and economic indicators are used to characterize and predict changes in activities, attitudes and institutions. Categories of cultural descriptors include: publics, networks, settlement patterns, work routines, supporting services, recreational activities, and geographic boundaries.

Cultural descriptors are used to describe the way of life and special characteristics of people living in a given geographic area. Used in combination, the descriptors characterize how multiple publics live their daily lives by 
describing where they reside, work and recreate, and also how they take care of each other and manage their environment. By being involved in the characterization process, resource managers can become more aware of how people's interests and activities have ongoing influence on resource use and, conversely, how resource management activities have a constant influence on people's lives and their environment (Greiwe, 1979).

By the same logic, understanding the social considerations involved in resource decision-making is a prerequisite for a resource manager who is interested in developing management programs that contribute to the well-being of the public. Through their involvement in the HRU characterization process, managers become more aware of how people's interests and activities influence resource use and, conversely, how resource management activities are a constant influence on people and their environment (Griewe, 1980).

\subsection{HRU Uses}

Griewe notes that HRU delineation can/should be used as a means of visualizing how people's activities influence resource management and how management decisions influence people's activities. How HRU boundaries change over time as settlement patterns, work routines, or physical access to an area change can be emphasized, as can economic well-being as a whole.

According to Griewe, the HRU is an effective analysis unit for designing, implementing and evaluating management actions that respond to the 
specific social conditions and resource uses at the local level. It provides a context for evaluating public issues, management issues and management opportunities (ICO's) unique to a particular geographic area. The management questions posed at the site-specific HRU level provide an indication of the overall questions to be resolved by an organization. HRUs are meant to be applied to day-to-day operations, long-range planning and project assessments in Forest Service planning.

\section{Day-to-Day Operations}

HRU's can be used for maintaining contact with diverse publics associated with resource decision-making, for monitoring changing public activities, attitudes and social conditions that influence resource use, and for identifying public issues and management concerns that require immediate attention. Additionally, the units can be used in evaluating the effects of current resource management programs on local, regional and national publics.

\section{Long-range planning}

HRUs can be useful tools for identifying public issues and management concerns that require long-range planning attention, tying issues to specific publics and distinguishing between local, regional, and national public issues influencing management. They can also be used in determining management opportunities that resolve issues and concerns that are unique to a particular geographic area, insuring that planning alternatives are responsive to the 
identified public issues and identifying other agencies/organizations with which consultation is advisable.

\section{Project Assessments}

HRUs can also be useful in establishing a data base suitable for the completion of an Environmental Assessment or Impact Statement and for predicting the effects of a change in resource use on the people of a specific geographic area. Finally, the HRU can be used for designing resource development alternatives that maximize benefits for, and mitigate the impacts on, publics at local, regional and national levels and insuring cooperation with other agencies/organizations responsible for addressing the issues and concerns involved in the decision-making process.

\subsection{Defining the Cultural Descriptors Utilized}

The "publics" cultural descriptor is meant to identify publics that influence resource use locally or live elsewhere and have an interest in the way resources are managed. Table 3.1 identifies typical sources of publics (Soderstrom, 1981). By informally identifying publics and characterizing each public's interests, a resource manager can determine how segments of a population are affected differently by resource decision-making.

Similarly, the "networks" cultural descriptor is generally defined as a structural arrangement of individuals who support each other in predictable 
ways because of their commitment to a common purpose, their shared activities or similar attitudes. A knowledge of the networks people form to express their interests is essential for identifying public issues relating to resource management, and for monitoring the effectiveness of resource management programs.

\subsection{Monitoring}

The whole purpose of the HRU monitoring process is to improve resource decision-making. The HRU characterization should provide up-to-date information on the economic and social environment in which a resource manager operates. As a shift occurs in the cultural and economic descriptors, a shift can be expected in resource use, which in turn affects the way resource programs are managed. A manager can monitor and respond to the changes in local society, or can wait and react to the changes after they affect resource use. Monitoring is thus defined as a process for determining how well management objectives have been met, how closely management standards and guidelines have been applied and whether identified public issues and management concerns are being incorporated into ongoing planning and management processes. 
Table 3.1: Typical Sources of Publics

Governmental:

In-Service Data Sources (e.g. public participation data, personnel, maps, computer inventories, and environmental documents)

Planning Agencies (state and local)

State Departments

County Engineers

Council of Governments

County Extension/Resource Agents

Economic Development Groups

Employment Service representatives

Pollution Control Agencies

Redevelopment Organizations

School Superintendents/College Presidents

Social Service Representatives

Special Authority/Commission Representatives

Universities

Private:

Business and Industry

Bankers

Community Leaders

Knowledgeable Private Citizens

Newspaper Editors

Plant Managers

Private Carriers

Realtors

Retailers Associations

Social Organizations

Special Interest Groups

Union Representatives

Utility Representatives 


\subsection{Agency Directives}

Recent agency directives call for an optional social and economic reference document (an overview) which may be prepared during scoping ${ }^{2}$ for forest land management planning or other major actions (USDA Forest Service Handbook $31.51,1985)$. Like an HRU, an overview may be a very general document for use as a reference in routine Forest planning or a more focussed report dealing with the social and economic context and possible effects of a site-specific action. An overview is a published or unpublished report, or an accessible file of data with a summary and interpretation in narrative form. The overview may contain social and economic data of general interest, such as basic economic data, labor force characteristics, population characteristics, income distributions, industry trends, resource supply needs, transportation factors, land use patterns, and pertinent social and cultural information.

According to agency guidelines, a well-designed social and economic overview describes the social, historical, and economic context of a Forest Service Unit and identifies problems, opportunities, and potential sources of controversy. It includes the most recent and reliable social, demographic and economic data, and discusses socioeconomic and sociocultural trends pertinent to Forest programs. Additionally, it may identify important relationships among physical, biological, economic and social aspects of Forest management,

${ }^{2}$ Scoping is the public participation forum for determining significant issues, developing reasonable alternatives, and determining the format of the required documentation that follows analysis. 
facilitate the design of effective public involvement programs within the area of influence, and organize appropriate social and economic information for developing Forest plans, programs or project-specific environmental documents.

\subsection{Summary}

An organization's success at implementing a particular resource program usually depends on how well the public understands its purpose or participated in its development. When a selected program direction reflects an honest consideration of public issues, there is greater chance for decisions to be accepted, even by those who do not agree with the decision. In daily operations, an awareness of the social environment assists a manager to reach decisions that resolve public issues rather than create new ones.

SRM aims at trying to achieve the public perspective rather than from an individual agency perspective through SIA, public participation, and HRU documents. However, agency directives for such extensive social assessment is ambiguous. Chapter 4 discusses the dilemmas of Forest Service public participation and Social Impact Assessment processes. 


\title{
CHAPTER 4 \\ PUBLIC PARTICIPATION AND SOCIAL IMPACT ANALYSIS
}

\author{
"Planning and management objectives should reflect \\ not only biological and physical conditions, but also \\ social acceptability." \\ - Baltic (1987)
}

Being sensitive to the social environment in which an agency operates is a required skill for staff at all administrative levels. When an issue is identified locally or regionally, there must be a process in place for evaluating its significance to the public and its implications for the agency. The specific cultural, political or economic factors contributing to the emergence of an issue need to be spelled out so that personnel responsible for responding to the issues have a common definition of the context. Responding to issues solely from a forestry, hydrology or biology perspective can often be disastrous for a resource specialist or manager. Without an awareness of the societal considerations involved, the agency can arrive at a professionally sound decision that is far from being socially responsive to the affected publics.

The role of social analysis is to improve the usefulness of information available to the public and decision-makers for resource allocation purposes, to permit better understanding of the resource tradeoffs among various planning alternatives in their economic, social and environmental dimensions and, to assist in assessing compatibilities and conflicts among various resource objectives and social groups (Palmer and Tremaine, 1982). 


\subsection{Public Participation}

Nelkin (1982) raises several questions: Who should participate in major policy decisions affecting the environment? What is the appropriate role of expertise? How is it possible to include those affected by environmental policy choices in the process of decision-making in complex, technical areas? She notes that as administrative bureaucracies grope for ways to include citizen feedback in their decision-making procedures, they do so with great ambivalence. The agencies fear that increased public participation may threaten bureaucratic authority and future economic development. They struggle with the problems of defining the public and of establishing appropriate goals when more people are involved in decision-making procedures. Additionally, agencies anticipate a deluge of demands by non-represented public interests or by selfappointed environmental elites, and they fear this will significantly undermine the administration's efficiency and autonomy. Indeed, the debate over the use of natural resources is paralleled by a debate over the extent and form of public participation appropriate in environmental decisions.

According to Langton (1978), citizen involvement is not a technique; rather, it is a strategy, an approach, and a philosophy. Therefore, there is no one way to "handle" citizen involvement. He believes that no planner should allow a citizen-involvement program exclusive sovereignty over his or her interpretation of the public will, but the program can be used to show competing views of that will. Fundamentally, most participatory measures are directed to informing the public, or to informing the decision-makers, about 
preferences, needs, trends, and issues. They pose little real challenge to existing decision-making authority.

The Institute for Participatory Management and Planning (1986) contends that the lesson for the public agency isn't one of how to destroy an objector's credibility, but one of why it may be important to actively solicit a potential objector's participation from the outset and to do so in a manner that makes it abundantly clear that the agency is actively seeking his or her participation. One of the "facts of life" for government agencies is the conflict between political interests and technical interests in decision-making (Langton, 1978). The excessive practice of using technical justification to rationalize controversial political discussions is undoubtedly one of the factors that has led to greater demands for citizen involvement.

In all of these situations, a professional's ability to effectively solve problems depends just as much on one's ability to interact with the various interests in a community as it depends on one's technical expertise. Forester (1989) notes that sources of professionals' (especially planners') effectiveness and power exist in: widespread contacts, formal or informal bureaucratic and political pressure, bargaining with bureaucratic cooperation or possible delays, managing uncertainty and shaping images of the future, preempting definitions of problems and thus approaches to solutions, alerting, warning or working with "outsiders" (of bureaucracy), coalition building, and selectively calling attention to particular opportunities or threats. 
Public participation has been official Forest Service policy since 1970, falling under the "inform and involve" program (Culhane, 1981). Public participation can mean any mechanism that allows access to agency officials by groups beyond those who traditionally participated intimately in agency decision-making that is, formal and informal processes.

Land managers recognize that their relationships with local contacts are part of the public participation program. As the action arm of their agency, the people who deal with the agency's publics on a day-to-day basis, local administrators are inevitably drawn into the politics of agency decision-making. Individual, one-to-one interactions may not sound like a sophisticated public participation plan, but they are often a more effective mode of participation than a public meeting, where the public aspect tends to discourage candor, encourage tactical overstatements of positions, and inhibit two-way conversation (Culhane, 1981). Culhane also notes that recent public participation programs clearly illustrate the shift in public land politics from user-dominated local constituencies to balanced, environmentalist-user constituencies.

According to Krutilla and Haigh (1978), it is important to distinguish the different purposes for which public involvement is sought. Involving the local public in a review of management plans seeking to reflect national interests can be potentially destructive, depending on the conditions governing such involvement. Accordingly, public participation should involve the Forest Service in two kinds of activities pursuant to its legislative mandate. One consists of reaching outside of its own cadre for specialized expertise as provided for in 
the legislation. The second is to consult the publics to ascertain their preferences and needs to obtain the information necessary for planning efficient allocation and management of forest and rangeland renewable resources.

\subsection{Social Impact Assessment}

Social Impact Assessment (SIA) provides an overall framework for considering the effects of people on management of resources, and the effects of management of resources on people (the human environment includes the natural and the physical environment and the relationship of people to that environment). SIA is an important component in the analysis of such actions as legislative proposals, major agency policy changes, land management planning, and site-specific projects with human impacts.

\section{Objectives}

The stated objectives of the Forest Service's SIA program are: 1. to determine in a systematic manner the social effects of Forest Service planning and decision-making, and 2. to satisfy the requirements of the law and the Forest Service policy for social assessment. For an SIA report to serve legally required and variously desired purposes, it has to give the reader a sense of how prospective and/or actual development is perceived by the target area residents - lifestyles, sense of well-being, social systems, human relationships (Jain and Hutchings, 1978). NEPA requires that unquantified environmental 
amenities and values receive the same serious consideration as economic and technical factors (USDA Forest Service, 1978).

Additional objectives of conducting an SIA are: 1. to inform agency decision-makers and publics of the variety of potential social effects that might occur as a result of agency actions, 2. to identify potential public needs and concerns that resource managers must consider in their decision-making, 3. to assess the effectiveness of program planning, implementation, and social impact mitigation. Most social impact analysis in the Forest Service is the work of interdisciplinary teams responding to NEPA and NFMA requirements.

The President's Council on Environmental Quality (CEQ) was the agency responsible for clarifying the link between NEPA and human populations. The CEQ expressed that qualifying actions (for EIS) must be major, must clearly be a federal action, must have significant effect, and must involve the "quality of the human environment, either by directly affecting human beings or by indirectly affecting human beings through adverse effects on the environment." The quality of the human environment provision and the interdisciplinary approach of the law clearly makes social considerations an integral component of all required EISs.

Environmental analysis, including SIA, is considered to be a flexible process that permits variations in activity sequence and revision of earlier work as the analysis proceeds (USDA Forest Service, 1978). The social information required for each analysis varies with the type, complexity and social importance of the proposed action. Field personnel and managers are 
encouraged to use valid existing documentation in each analysis, to avoid duplication of efforts. ${ }^{1}$

In scoping the current social situation and the possible effects that could result from proposed actions, personnel are directed to consider the following: 1. categories of people the activity is likely to affect,

2. how the action compares with historical trends - past and present economic activities, rates of population change, community stability, and local traditions, 3. socioeconomic and sociocultural conditions the action is likely to affect, 4 . sources of effects: direct, indirect, induced and cumulative, 5. duration and intensity of effects: short or long term; how significant, 6. location and magnitude of the action: whether it is local, statewide, regional, or national in its effects, and 7. ask the questions, who uses the resqurce of the Forest Unit? Does the Unit supply a large portion of each user's needs for goods and services? Where National Forest lands are involved, what activities or conditions occur on adjacent lands, and what are their ties to the National Forest? If the proposed action is site-specific, do some individuals and groups have strong feelings about its location and desirability?

\section{Economic and Social Effects of Management}

The purpose of examining socio-economic effects, they determine, is to predict the impacts of Forest management on local communities (Moore et. al., 1982). Socio-economic effects, or impacts, are simply those changes that happen

\footnotetext{
${ }^{1}$ Appendix $\mathrm{D}$ is a list of possible data sources for SIA.
} 
to people because of the way a Forest is mianaged. âmede: effects might include a phase-out of traditional industry with a loss of jobs, or the expansion of a small local industry to meet new needs and appoptunitibs offered by the Forest. Socio-economic effects include changes in thewato foridst fits with people's way of life, as management practices becontiegere or less compatible and supportive of the way things are done in alsompanghanges in how a Forest is managed may also affect how peoptabilityabund their lives, their community, and their environment. The effectacofi.Foresi shanagement also reach beyond local communities to people muliutevenifescaway and who rarely visit the forest. tificant, 6. loc ti tewide, region

\section{A. Economic impacts}

Many of the effects of Forest management decisions come from the Forest to people by way of the economy (Paldher andattremaine; 1982). A Forest provides commodities and opportunitiether leieal,istate and national economies; buys goods and services from theserecoirutivizs; and employs people who spend their money in those economiesatitiother economic link is the payments which go from the Forest Service to county governments in lieu of taxes. If different alternatives will change the returns to counties, then the quality of local services, from roads to schoiolsffedts,chboge anless local taxpayers make up the difference. The ForecalSeorimauatiso cooperates in many programs with state and local governmentsimply those of 
The Forest Service's role in addressing the issue of community stability is not to assure that adequate demands exists for what a local economy produces. While the Service may purchase products from the local community, the Service cannot control the aggregate demand for the community's outputs. The Forest cannot purchase surplus outputs which may arise as a result of a general decline in demand or a periodic fluctuation. The ability of a Forest to counteract periodic fluctuations in aggregate demand is very limited. For example, managers can mitigate the impacts of a severe loss to a community by slowly phasing a program out rather than by making abrupt radical changes.

Additionally, shared receipt payments related to National Forest System lands include receipt-sharing of gross payments collected for outputs (USDA Forest Service, 1988). A share is given to state governments for redistribution to county governments. Payments in lieu of taxes are also made by the federal government. The payments are generally used for schools and roads.

\section{B. Social impacts}

Forest management decisions affect people through paths that do not pass through the economy or local government (Moore et al, 1982). Recreationists' satisfactions with themselves and their quality of life can be directly influenced by the changes in recreation opportunities and qualities on the forest. Management practices that change the perceived environmental quality of an area change the attractiveness of that area for its residents. The amount of regulation of activities (such as camping, firewood, or greenery 
picking) affects how people feel, particularly if they have always seen the Forest as a place to get away from rules and regulations. Management prescriptions that may conflict with how some people think of the forest have direct social or psychological impact on those people and may increase the level of conflict within the community. Access to decisionmakers and opportunities for public participation are additional social parameters of concern.

\subsection{Summary}

Problems in conducting an SIA often include questions of: 1 . Who is responsible for completion?, 2. Are there agency guidelines for a uniform methodology?, 3. What level of detail is appropriate?, 4. How does the Forest Service carry out its mission and still respond to the social environment? There is often a gray area between SIA and mitigation efforts of local, state, and federal agencies. There is widespread concern that the Forest Service does not consider social effects beyond completion of the SIA documentation. Additionally, the Forest Service does not always have the authority or responsibility to control impacts.

The 1984 Social Analysis in Land Management Planning Workshop provided the following internal Forest Service recommendations for the improvement of the SIA process on the Regional and Forest level: 
1. Develop, for possible incorporation into future plan revisions, positive "social objectives" for resource management.

2. Participate in professional societies with SIA interests, such as Natural Resources Research Group of the Rural Sociological Society or the American Society for Public Administration.

3. Develop social analysis standards for land management planning similar to the analysis standards applied to other resources.

4. Use social analysis in implementation and monitoring phases to identify potential problems that can or do arise when prescriptions are applied to specific areas. 


\section{CHAPTER 5 \\ SOCIAL INDICATORS APPLICATION}

"In the human community we have never fully exhausted our powers of analysis until we have also understood the participation of the individuals in common enterprises, the sharing of common hopes and ideals, and the mechanisms of communication and social interaction which are not built into the organisms but which exist in language, collective symbols, laws and customs, in short, a social heritage."

- Burch and DeLuca (1984)

All resource management professions and agencies claim to have certain goals they hope to attain. The professions and the agencies involved in achieving these goals use some measure that stands for the larger goals or variables they are engaged in pursuing. Use of recreation visitor days, growth volumes of forests, storage rates of water, and a variety of other indicators monitor success and failure in accomplishing certain resource management goals. In addition to natural environment goals, agencies are mandated to "deal" with the human environment, specifically in measuring the impact of their resource management choices on the human communities and lifestyles in a national, regional and local framework.

There is no set of standard issues that agencies are required to address because of the diversity of publics and geographic areas that public land management impacts. Issue, concern and opportunity (ICO) identification is part of the informal National Environmental Policy Act "scoping" process for every significant agency action, including plan development. Public issues are defined as subjects or questions of widespread public interest relating to management 
of the National Forest System (USDA Forest Service, 1986). Management concerns are issues, problems or conditions that limit the range of management practices identified by the Forest Service in the planning process. Management opportunities pertain to the capability of the Forest to respond to issues and concerns. The purpose of identifying issues and concerns is to determine the quality and quantity of goods, services, uses, and environmental conditions that people want from the Forest.

The development and maintenance of a substantial data base for longterm resource planning, assessing the social effects of various forest resource actions at a low cost is imperative for comprehensive National Forest planning. The abundance of vital information available at the State, County and Town level, is often inaccessible to planners. Information maintained by different town, state, and federal agencies must be in a standard form if it to be utilized readily by all involved in planning processes. Forest planners are faced daily with questions regarding capacities of facilities, permits, economics, fiscal impacts, environmental concerns, demographics and social relationships. To provide more accurate responses to these questions, the use of an integrated, dynamic, spatial database is a necessary component in the manipulation of pertinent data to provide the answers.

Agencies generally have a particularly limited capability to track systematically what is happening to rural society, except in the most aggregate sense, and thus little ability to describe many problems concretely or to develop policy to deal with those problems (Gilford et al, 1981). Because rural 
development goals often include meeting basic needs, economic security, education, natural resource protection, and equity, information on the disparity between these goals and reality, as perceived by rural people, is useful to policymakers. The need for particular attention to the data base for rural areas derives from the inherent physical characteristics of rural society. Cooperation in the development and management of data bases across many organizations at federal, state, and local levels of government is necessary. A social indicator program might provide the theoretical basis for such a database.

\subsection{Social Indicators: Definitions}

Social indicators may be defined as measures of social conditions in a population or sub-group and of situations presumed to be directly linked to human needs. In terms of their primary function, social indicators may be described as filtering devices which aid our comprehension of the broad significance of changing social conditions and trends (Johnston and Carley, 1981). They do this by focussing our attention on a limited subset of key social information. To determine the appropriate composition of that subset, it is first necessary to identify those conditions or processes that constitute important components of well-being or areas of social concern. Second, observable and measurable attributes or manifestations of those components must be specified so that their status may be objectively ascertained. Broadly speaking, social indicators may be designed to serve five main purposes: description, analysis, 
program evaluation, policy development and normative considerations (OECD, 1977).

\subsection{The Process of Establishing an Indicators Program}

Worton and Morgan (1975) identify four distinct steps

in the process of creating a set of indicators:

Step 1. Determine the purpose of the indicator program.

Step 2. Decide what specific information is needed to satisfy the purpose.

Step 3. Determine the appropriate level of aggregation for the indicators selected.

Step 4. Decide how the indicators can be analyzed to determine whether the purpose has been met.

Johnston and Carley (1981) remark that the purpose of social measurement is to obtain reliable estimates of selected quantifiable aspects of social phenomena that are of interest for a variety of reasons. Social indicators constitute a subset of social measurements and other forms of evidence that inform us about current conditions and emerging trends with respect to those aspects that relate to human well-being or to major areas of social concern. Technical, sociopolitical, and communication problems impede the effective collection of information for and presentation of information to both policy makers and the general public. Indicators are clearly not a panacea, rather, they are one lens through which to see and understand complex social phenomenon. 
deNeufville (1981) also notes that the crucial phase in solving a problem is the process by which it comes to be defined. The information needed to understand the problem depends on one's idea for solving it and the process of formulating the problem and of conceiving a solution; there is a clear interdependency between perception and solution. In this respect, numbers (that is, statistical indices or measures) provide a ready way of formulating a goal or defining a norm. Statistics become simple, forceful means of communication and indicators are simply statistics that reflect directly on matters of public concern, indicators of specific phenomena, or aspects of life quality.

According to deNeufville (1979), the design of policy indicators includes not only the development of concepts and the gathering and manipulation of data, but also the design of institutions for the production, design and dissemination of indicators; the design of policy-making systems to use them; the development of client groups or constituencies who will protect them from manipulation; and the design of self-correcting systems to improve and redesign the indicator as necessary.

Social indicators may further be classified as objective and subjective (Schneider, 1976). Objective indicators are based on reports or situations that are traits of communities not necessarily interwoven into individual life experiences (e.g. income, environment, health, education). Subjective indicators, on the other hand, are based on survey research reports about life experiences and subjective evaluations of life conditions made by individuals (e.g. level of satisfaction with one's family life, job, etc.). 


\subsection{Problems with Indicator Development}

According to Schneider (1976), if social indicators had responded to the absence of good data in the face of rapidly increasing demands, they would today be tied intimately to all administrative processes and would have developed primarily to satisfy the information needs of administrators concerning the effectiveness and the efficiency of government programs. They would resemble performance measures and would satisfy the conceptual needs of the "New Political Economy" with its specific concern for measuring the interaction of government programs and societal conditions. Instead, most contemporary social indicators have sought to improve our ability to measure the well-being of society without specific reference to the role of government.

Plessas and Fein (1972) postulate that the principal barrier to successful quantifiable indicators in the long run is not a lack of meaningful data but a failure to define what is meaningful or to give operational content to our ideas. They note that most of the existing indicator data is compiled by a huge, decentralized, and inconsistent federal bureaucracy for management rather than planning information systems.

The familiar "ecological fallacy", wherein the relationships observed among variables in larger units are assumed to hold in units that comprise the larger ones, is a form of the "fallacy of the wrong level" (OECD, 1977). Meaningful comparisons of economic well-being among communities, regions, and program target groups require that wages, salaries, income, net worth, 
transfers, outlays, taxes and other dollar indicators be expressed in comparable units.

\subsection{Application to Forest Service Social Impact Analysis}

Whorton and Morgan (1975) note that as aids to communication, indicators have three distinct applications: 1 . They can be used as a management information data base, 2 . They can be used for a periodic report designed to describe the quality of life in the community or to report significant public activity, and 3 . They can be used to provide information about special issues and problems such as major agency projects. By establishing criteria for the kind of information gathered and by requiring that all data be standardized, it is possible to create a data base that has much greater utility. Whorton and Morgan conclude that the key to using indicators as an aid in communicating with various audiences is the inclusion of both direct and indirect influences on the subject being studied and the presentation of the material in both statistical and visual modes.

Forest Service protocol for social analysis implies that the criteria for indicators must be: simple, systematic, quick, inexpensive, legally acceptable, and comprehensive. The broad agency policies of "caring for the land and serving the public" are but two of the many contextual goals the agency operates under.

Social impact analysis (SIA) encompasses social conditions and processes that are development-related and include the problems, dilemmas, hopes, 
confusions, anxieties, interests and needs of communities (Jain and Hutchings, 1978). As with much applied social science research, impact assessments are part of a broader movement to "scientize" public policy (Soderstrom, 1981).

The United States Congress granted environmentalists one of their first significant victories with the passage of the National Environmental Policy Act of 1969 (NEPA). Section 102 of NEPA made the following "social" requirements: 1. utilize a systematic, interdisciplinary approach to insure integrated use of the natural and social sciences...in planning or decision-making, 2. identify and develop methods and procedures to insure appropriate consideration of presently unquantified environmental amenities and values in decision-making along with economic and technical considerations, and 3. study, develop, and describe appropriate alternatives in any proposal involving unresolved conflicts concerning alternative uses of available resources (USDA Forest Service, 1986b).

Burch and DeLuca (1984) note that some questions involved in SIA completion are descriptive and relate to social characteristics, structure, and change of various client groups and affected communities. Another set of questions in the SIA relate to effects of a resource action: What social changes are going to happen anyway? What sorts of social patterns are going to remain constant? Which patterns reflect a direct response to the resource action? 


\section{Criteria for Indicator Development}

1. The indicators must be meaningful in relation to the program and they must be accurate.

2. Administrative discretion remains necessary, even when indicators are used.

3. Discussion and definition of policy issues must follow, including policy targets, program design and administrative applications.

Many commonly used indicators are merely administrative conveniences to protect the organization rather than the resources (Burch and DeLuca, 1984). Some are inadequate indicators of the variables and goals they purport to measure; others are used in ways that fall outside the intent of their creators. Johnston and Carley (1981) note that if social indicators are to be more than an arbitrary subset of social statistics, they must contain information that is significant for purposive human action. They must therefore incorporate an orientation toward the agency's future management rather than merely accounting for past trends and developments.

\section{A Dual Qualitative and Quantitative Framework}

A qualitative framework can be predictive despite its lack of quantification, while a quantitative approach provides the desired measurements of social change. The qualitative framework improves the predictive capacity of an existing qualitative model by providing historical and site-specific information. A quantitative approach incorporates a quality of life model and a systems simulation framework (Jain and Hutchings, 1974). 


\section{An Example}

Burch and DeLuca (1984) cite one innovative example of social indicator application in the Forest Service planning process. Key informants were used in combination with qualitative indicators by Hutchins on the Okanogan National Forest (Washington State). Hutchins and his colleagues assembled and analyzed an impressive array of secondary data to develop social indicators. They then conducted open-ended interviews with 44 persons who represented categories of resource and non-resource based interests and values. Hutchins asked four clusters of questions to trigger discussions by his "informants":

1. How have past-to-present events shaped your lifestyle and your values?

2. What do you foresee as future events that will affect your lifestyle and your values?

3. What do you conceptualize as major events in the history of your area?

4. What is the name of the group or sector that you identify with; what are the percentages of the total population that each group occupies and how are their numbers changing?

Key informants are generally defined as knowledgeable residents who can provide information (primary data) not available elsewhere and they provide a "built-in" time series. According to Burch and DeLuca, the study is an excellent example of combining quantitative social indicators with qualitative data from key respondents to make natural resource policy more socially responsive. Furthermore, the work provides a substantial data base for long-term resource planning at a very low cost. Burch and DeLuca offer an introduction to other 
techniques of time-budget, life cycle, adoption, community, regional, and social survey approaches to human resource systems.

\subsection{Social Indicators Implicit in the Forest Service's Implementation of SRM}

The preceding discussions of related legislation, SRM program in Region 2, and social indicators point to a series of "implicit" questions that should be integrated into the Forest Service's use of HRUs. These questions may be answered through the judicious combination of quantitative and qualitative techniques, thereby expanding on Hutchin's work. These questions include the following:

1. Will proposed resource management programs affect the size of local or regional populations? Will proposed programs significantly affect the characteristics of the local population? Will the character of local communities be influenced as a result of these changing settlement patterns?

2. How will proposed management programs address the interests of those publics that use the resources at a local, regional, and national level? What public activities will be encouraged and discouraged by the proposed management direction? What public perceptions about proper management of natural resources will be enhanced or aggravated? What changing expectations might new publics have about the way resources are managed?

3. Will proposed resource management programs introduce newcomers to the local area with different values and routines? How might the cooperation or cohesion among social networks in the community be altered as a result? Will proposed programs increase the presence of regional and national networks 
functioning locally? Will the involvement of outsiders be such that local networks could possibly lose their sense of control over their desires futures? Will the direction of proposed programs impact citizen networks such as seniors, youth, racial and cultural minority populations, women, or the disabled? How will special beliefs and customs of networks such as Native Americans be considered or not considered?

4. Will proposed resource management programs influence the number of jobs available locally? Is the proposed level of program outputs and activities expected to increase, decrease or maintain current resource-related jobs? Will proposed programs generate the types of jobs that can be potentially filled by local residents? Will proposed program direction enhance or aggravate the current mix of employment activities? Are new or increased employment opportunities likely to bring more economic diversity or changes in the way of life to the area? Will proposed program outputs and activities influence the local wage structure? Will proposed management programs influence the number of jobs available to regional or national publics?

5. How will the production of resource outputs on public lands contribute to the county tax base through payment in lieu of taxes (PILT) funds and other programs? How will the economic activity generated by resource programs contribute to the amount of sales tax collected by local and state governments? Will the future emphasis of resource program activities place additional pressure on community support services and activities? Which social services, volunteer organizations, and informal "caretaking" activities might have to accommodate more demands? How are communities affected by resource management activities likely to control and manage their futures? How might the quality of life be altered as a result? Will resource programs rely on the support of other local, state or federal institutions? Which governmental organizations might have to enter into cooperative agreements? How is 
cooperation between organizations likely to improve the level of goods and services provided to the public as a result?

6. Will proposed resource programs affect the recreational opportunities available to the public? What level of recreation will be provided for and how is the anticipated amount of recreational use likely to be accommodated? Will proposed programs attract additional users to the area? What types of activities will be emphasized for regional and national users? Which sites and facilities are designed to accommodate their recreational preferences? Will proposed programs influence recreation-based businesses? Are the seasonal fluctuations in tourist-related businesses being addressed through the proposed recreation program direction?

7. Will proposed resource programs encourage any significant shift in land use? How are the ratios between agricultural, residential, industrial and public land use likely to change? Are land speculation and investment activities likely? Will the direction of proposed programs eventually alter the unique character of the geographic area? Will proposed resource programs affect the ability of local governments to control future land and resource use? Is the amount of open space or other unique characteristics of the land likely to be altered as a result? How might improved access to the area eventually alter the established community way of life? 


\section{CHAPTER 6 \\ PROGRAM EVALUATION}

A number of approaches are available for evaluating the Forest Service's HRUs. Dunn's (1981) retrospective process evaluation and decision-theoretic multi-attribute utility analysis provide two such methodologies. The following informal evaluation is primarily concerned with retrospective process techniques. Retrospective process evaluation involves the monitoring and evaluation of programs after they have been in practice for some time and requires a wellestablished internal reporting system. Management information systems in public agencies sometimes permit retrospective process evaluations, provided they contain information on processes as well as outcomes.

Human Resource Units are an integral part of the Socially Responsive Management program established for Region 2 of the National Forest System. Their development and use as "policy" on the Shoshone National Forest has been sketchy for a number of reasons, including internal agency guidelines implemented since Plan completion and lack of monitoring. ${ }^{1}$ The SRM program was designed to incorporate much more than Plan development.

The following evaluation addresses much more than simply the Forest's application of Human Resource Units to achieve its numerous goals and objectives. The evaluation is aimed at restructuring the use and development of HRUs by identifying "holes" in day-to-day, project, and long-range planning

\footnotetext{
${ }^{1}$ Chapter 1909 of the Forest Service Handbook provides agency guidelines for social and economic analysis (USDA Forest Service, 1988).
} 
applications. In broad brush, the evaluation addresses three questions: Is the agency open to public (especially local) input? Do agency procedures ensure democratic responsiveness to the public's wants and needs? And, is the agency meeting expectations? legal directives? agency goals?

\subsection{Evaluation}

A. What is essential to the program? How is the agency achieving its desired goals/ends/models of service? What are the most successful techniques employed?

\section{$H R U$ guidelines}

There are no agency-developed guidelines for the use of HRU's or the implementation of the SRM program. In the early 1980's, the Foundation for Urban and Neighborhood Development (FUND) organized a series of training sessions and workshops for its clients nationwide. Forests in

Region 2, which were developing Forest Plans at the time, applied the SRM methodology to their planning processes at their own discretion. The Shoshone National Forest Land and Resource Management Plan refers to HRU development in the Social Assessment section. ${ }^{2}$ Documents were completed by District personnel and reviewed by the Forest Supervisor. Compliance with

${ }^{2}$ This section of the Plan is approximately three pages long and makes a vague reference to HRU documents and other planning records. 
NEPA requirements for social assessment of the Forest's "impact area" were not challenged by public intervention or administrative appeal.

\section{HRU uses}

Project planning, long-range planning, and day-to-day management are the suggested applications of SRM and HRU's (e.g. SRM as a management philosophy rather than support activity or program coordination). Since 1985, SRM has been displaced by both Forest Service Handbook and Manual amendments directed at social and economic analyses and apathy for social assessment in general.

\section{Planning Process}

Plan development, monitoring, evaluation, and amendment processes are the primary steps to land and resource management planning. The statutory mandates discussed in Chapter 2 provide the framework for agency operations. To be used effectively to this end, HRU development and updating should occur in the initial stages of plan development or amendment. The Shoshone is presently in the process of developing a Plan amendment and data collection for completion of all required analyses has begun.

\section{District input}

Personnel identification of goals and management concerns at the field office level are important because of ongoing interaction with numerous publics. 
Development of informal communication networks provides the basis for solicited public participation activities that would not otherwise occur. Appendix E contains an outline of Shoshone ranger district specific concerns and current issues that are the result of changes in the Forest's management situation.

\section{NEPA-mandated scoping}

Identification of and communication with key informants through an active Forest list of contacts, participants, interest groups, etc. is often key to project approval. Scoping is often the first contact between the resource managers and the concerned public. As noted in Chapter 1, NEPA and NFMA both express public participation requirements.

Data collection and periodic update

Data collection for social and economic analyses was completed in 1980 with the development of Forest HRU's and completion of IMPLAN, the Forest Service's input-output modelling program. In 1989, revision of that data (populations, employment, economic profiles, land use patterns) was begun. Periodic update, monitoring, and assessment of data has been notably absent from the Forest's planning process. Mandates for monitoring and evaluation have been neglected. 


\section{Tiering}

Use of the documentation/data and assessment in other assessments and/or planning documents is often an effective means of preventing a duplication of efforts. An essential problem with this is the dynamic nature of the Forest's social and economic environment and the static nature of the completed assessments. Assessments tend to be outdated almost immediately. ${ }^{3}$

Project checklist

In 1988, a procedure was established to assure compliance with the Forest Plan for all proposed projects. This procedure involves developing a checklist for each project during the environmental analysis of that project. The checklist is a listing of all the standards and guidelines that pertain to the specific project and the design requirements from the relevant desired forest conditions (goal) selected for the project area. Such a checklist accomplishes much of the purpose of monitoring as listed in Chapter IV of the Plan (USDA Forest Service 1986 and 1988).

Review of plans and land use policies of other agencies

Agency guidelines include consultation with local and state planning agencies on every significant project. A suggested list of Forest contacts is provided in Appendix E.

${ }^{3}$ An example of such a document is provided in section 6.2. 
B. Goal identification

Goals for management of a particular National Forest are developed by: 1. identifying issues, concerns and opportunities and summarizing them into planning statements, 2. identifying Forest conditions which, if achieved, would solve each planning problem, and 3. grouping these Forest condition statements, where compatible, to form goal statements (USDA Forest Service, 1988). The Forest Plan establishes, by geographic area, what goals (desired Forest conditions) are to guide the selection and design of activities. In each area, these desired conditions are to be used as a guide to selection and design of activities over the ten-year planning horizon.

C. Translating goals into measurable indicators and collecting and analyzing data on those indicators.

Public response to document review

As required by the Administrative Procedures Act, agencies are required to provide public access to published documentation and management files. Additionally, NEPA requires that environmental assessment documentation is reviewed by the public and other agencies. Public comment is often solicited by means of Forest mailing lists. Lists often include special interest organizations and individuals who have expressed concern about forest management and projects. This procedure has been quite efective at stimulating a response. For 
example 185 response letters were received for the June 1985 DEIS for the Forest Plan.

Attendance at public meetings

This information is available in standard public participation statistics which can be disaggregated for projects or issues. Recorded attendance and meeting notes are also public record and are often published by the local media. These statistics are often used as informal indicators of public concern over an issue.

Number and nature of administrative appeals

Administrative appeals are the final avenue of public protest offered by the Forest Service. Appeals are registered with the Regional Forester's Office (e.g. Wyoming Heritage Society appeal of the Plan DEIS, May 1986) and include an explicit statement of reasons for appeal. Appeals are reviewed by the Regional Forester, who has the discretion to address the concerns of the appeal and review project procedure and content. Litigation at the federal level is often curtailed by this internal agency process. 
D. Input measures

Interdisciplinary team selection and coordination

In accordance to NEPA requirements, each project (including Plan development) has an interdisciplinary-team (ID-team) of 5 to 10 persons, usually consisting of Forest Supervisor's staff and appropriate District personnel. Participation on ID-teams is rotational with the exception of the planning staff officer, who coordinates most teams.

Source of funding

The ability to implement a Forest Plan depends to a strong degree on the budget received by the Forest. Budget proposals must be based on the estimates of budget needs in a Plan. Forest budgets are submitted to the Regional Office; a Regional proposal is then sent to the Chief's office where it is combined with budget proposals from all other parts of the Forest Service; this is then reviewed by the Department of Agriculture as well as by the Office of Management and Budget (USDA Forest Service, 1988). Congress then decides how much money, by functional area to allocate. Budgets over the last three years have been lower ( 30 to 50 percent) than those called for in the Plan. A re-evaluation of Forest budgeting was completed in 1988-1989. 
Capacity of facilities and resources

The Forest's approximately 2.5 million acres have an enormous capacity for multiple-use activities. Access to the Forest and restricted uses in designated Wilderness areas are the primary limiting factors to use. Since 1986, there has been no systematic process for estimating actual recreational use of various types on the Forest (USDA Forest Service, 1988). Estimations of recreation use and predictions of future demands will most likely take the form of qualitative assessments in the forest's amendment process. Servicewide directives for recreation-use emphasis include measurement of a variety of uses from sightseeing to dispersed recreation.

\section{Direction of management}

Identification of a "preferred alternative" was completed in the Plan EIS process in 1985 and approved by the Regional Forester. This alternative was applied to areas of the Forest through FORPLAN (linear programming) prescriptions and identified "desired Forest conditions".

This alternative places non-commodity uses above commodity demands. Seemingly arbitrary quantification of non-commodity uses is often the impetus of public concern and is removed from the "human factors" of resource management. 
E. Workload indicators

\section{Programs}

The number of persons employed by the Shoshone varies annually, but hosted Human Resource Programs include: Job Training, College Work Study, Vocational Education, Work Incentive (WIN), Community Work Experience Program, Workfare Program, Vocational Rehabilitation Program, and NonFederal Programs. The Forest Service Manual, Title 1800 Human Resource Programs, Chapter 1810 and Catalog of Federal Domestic Assistance provides an explanation of programs which were developed at the national level and implemented in the advent of SRM implementation.

\section{Volunteers}

The number and function of volunteers varies annually. Volunteers usually work at the District level on supervised projects. Many organized groups volunteer on a daily basis (e.g. Boy Scouts who do supervised trail maintenance for a weekend).

\section{Level of inter-agency communication}

Translation of Forest goals and comprehension and implementation of the Forest planning process and NEPA procedures on a District level are the subject of periodic workshops and training sessions held by the Shoshone's planning staff officer. Improper implementation of the Plan has occurred based 
on misunderstanding and, in part, because of the way in which budgets are allocated. ${ }^{4}$ Some types of projects have not received the attention called for in the Plan. There is a need for better understanding of Plan implementation (USDA Forest Service, 1988).

F. Efficiency measures

What is processed?

Public issues, management concerns and opportunities (ICO's) are identified in the NEPA scoping process and plan alternatives are developed with the goal of resolving some combination of ICO's. Issues are legitimized by answering several questions: How widespread is the interest in the issue? What is the level of interest in the issue? How long will the issue remain a point of contention for publics and management and why? Management concerns, on the other hand are based upon laws, regulations, policy, public issues, past and present trends, and predictions about resource use. "Walk-in" information requests are directed to appropriate staff as needed.

\section{How many requests are made?}

No $\log$ is presently kept of phone calls, letters, editorials, petitions, etc. aimed at agency responsiveness.

\footnotetext{
"Administrative appeals that are "lost" by the forest
} service result in administrative reprimands. 
An information officer could develop such statistics as public participation information.

Special services required and provided

Many agency offices double as public information centers. Project scoping often includes field trips and site inspections led by agency personnel for interest groups and concerned citizens. Many other special services are provided. For example, the Interagency Grizzly Bear Management Team provides services to outfitters and guides operating in sensitive grizzly management situations.

G. Community indicators

Client Group Analysis or Stakeholder Analysis

The questions: Who are the "clients"? Who are the potential clients not being served? Why aren't they being served? would be the focus of such an analysis. Forest public participation lists and HRU development provide a weighty list of "clients". HRU guidelines indicate that land managers should look well-beyond active interest groups in the identification of publics to include even the non-user with option demands for resources. 
Are clients satisfied with the level of service provided? With the resources provided? With the special services and opportunities? How may this be measured?

Community sample survey

Any survey must be specially approved and funded by the Office of Management and Budget (OMB). Design and administration of a national resource-oriented survey would be cumbersome. Often local and regional concerns are weighted above national concerns in management practice.

\section{Solicitation}

HRU guidelines suggest the identification of local, regional, and national publics, with emphasis on local concerns. In 1989, the Greater Yellowstone Coordinating Committee identified community and public goals and objectives for the area by circulating public participation response forms. Over 500 comments were received and processed in the initial phases of plan development for the approximate 11 million acre region.

Cooperative efforts with local, state and federal agencies

In compliance with NEPA mandates, the Shoshone exchanges documentation and requests review of analyses by the following personnel: Wyoming Congressional delegation, Wyoming Game and Fish Department, U.S. Fish and Wildlife Service, Bureau of Land Management, National Park Service, 
WY Department of Environmental Quality, WY Office of the State Engineer, Bureau of Indian Affairs (Wind River Reservation), U.S. Environmental Protection Agency, WY State Conservation Commission, and WY Water Development Commission. Additional agencies and persons are noted in Appendix E.

H. Is the HRU an effective means for identifying publics?

Because Forest HRU's were developed in 1980 and have not been updated since, it is assumed that they are not an effective means for identifying publics over time. The development of social indicators for the Forest's planning area as discussed in Chapter 5 would add another analysis component to the documentation. Additionally, if timely HRU monitoring were to occur on a District level, the documents might provide a better management tool for the agency. Instead, District Rangers keep informal contact lists and make themselves highly accessible and visible as "good hosts" in local communities and at local gathering places.

Table 6.1 is a matrix rating the Forest's five existing HRUs. The rating system is a 1 to 5 scale, with 1 representing an absent characteristic and 5 being explicit inclusion. Characteristics rated include the seven prescribed "cultural descriptors" addressed in Chapter 3 and relevant social variables presented in Appendix E. Review of the HRU documentation included an assessment of how well the HRUs have predicted changes in the management situation. Such changes could be more accurately monitored if periodic update 
of a socioeconomic database were part of the day-to-day management practices of the Shoshone.

The matrix implies that the documentation is not uniform or systematically developed. This amorphic state of the documents is probably their most significant flaw. The matrix fails to address the key issue of HRU implementation into the day-to-day, long-range and project planning processes. Section 6.2 addresses this issue through summarization of selected forest documentation. 
Table 6.1: HRU evaluation

Cultural Descriptors and other indicators

Shoshone National Forest Human Resource Units

Unit Boundaries

\begin{tabular}{|c|c|c|c|c|}
\hline & $\begin{array}{l}\text { Big Horn } \\
\text { Basin Hes }\end{array}$ & $\begin{array}{l}\text { Lander- } \\
\text { Riverton }\end{array}$ & $\begin{array}{l}\text { Hind } \\
\text { River }\end{array}$ & $\begin{array}{l}\text { Wind River } \\
\text { Reservation }\end{array}$ \\
\hline
\end{tabular}

$\begin{array}{llll}4 & 4 & 4 & 4 \\ 4 & 4 & 4 & 2 \\ 4 & 4 & 4 & 2 \\ 4 & 2 & 2 & 3 \\ 3 & 2 & 2 & 2\end{array}$

$\begin{array}{ll}3 & 4 \\ 4 & 4 \\ 4 & 4 \\ 2 & 4 \\ 2 & 3\end{array}$

(11)

Area History

Settlement Patterns

Land Ownership Patterns

Influence of National

Forest lands

Publics

a. permittees

Pop. characteristics

a. population projections

b. school enrollment

Work Rout ines

a. economic profile

b. labor force

(6)

(9)

(17)

(20)

1

2

\section{3}

$$
1
$$

2

2

3

2

1

3

2

Communication Metworks

\begin{abstract}
a. formal
\end{abstract}
b. informal

Supporting Services

Recreational Activities

Trends and Predictions

a. Hater Quality and Quant ity

b. Hood Products

c. Recreation

d. Livestock Grazing

e. Wildlife and

Fish Habitat

f. Minerals and Energy

g. Special Land Uses

Key Informant Interviews

Contact Agencies

Completion Date

a. update

b. appendages

Preparers

Totals

(1) (3)
74

(2/81)

$1 \quad(5 / 81)$

3

56

Rating

1 = absent

2 = vague
$3=$ fair

$4=\operatorname{explicit}$ 


\subsection{Evaluation from Forest Documentation}

Retrospective process evaluation may also include the review of program documentation. Although the documents selected for review are not the HRUs themselves, they are primarily "decision documents" are influenced by preceding social analysis and Forest Plan development. These documents would all be strengthened by timely, detailed social analyses and dynamic information systems. Especially critical is the internal Monitoring and Evaluation Report for Fiscal Years 1986-1988. This document specifically address the issues and concerns that have developed since Plan implementation began in 1986.

\section{A. Monitoring and Evaluation Report Fiscal Years 1986-1988}

As discussed in Chapter 2, direction for internal Forest Plan monitoring and evaluation is found in 36 CFR 219.7 (f), which requires that monitoring and evaluation consider both the effects of National Forest management on adjacent lands and the effects of management of adjacent lands on National Forest management. Monitoring and evaluation of Forest activities and conditions in the four years since Plan implementation have been consolidated into one analysis document. Timely monitoring and evaluation have received low priority in terms of budgets and staff hours. 
Key recommendations from this report include:

1. Amending Chapter 4 of the Plan to modify monitoring items so that they are clear, measurable and indicative of affects of management.

2. The Greater Yellowstone Coordinating Committee should establish standard monitoring items and methods for the entire area.

3. Because there have been some problems associated with proper identification and design of projects, the ID team recommended that a program of ongoing training-in-use of Shoshone Management and Plan implementation be established Forestwide.

\section{B. Environmental Assessment for the Camp Creek Fire Rehabilitation and} Timber Salvage Project

This document is tiered to the FEIS of the Forest Plan and all appended planning records (This includes the HRU's completed in 1980-1981). Relevant sections of the Assessment include:

\section{Visual Resources}

Fire impacts on Highway 296, Beartooth Highway and the Clay Butte Lookout Visitor Information Services (VIS) Center are significant because these are 
state and national historic byways. Changed conditions in the area have impacted visitor-use and local quality of life values.

\section{Recreation Resource}

Highway 212 to Yellowstone National Park and the Park Road from the Northeast entrance to Gardiner, Montana, and Highway 296 and the Beartooth Highway (those roads that are being considered for timber hauling in the Assessment) are traveled primarily by tourists, and recreation uses might very well decline as a result of timber harvests. Also, firewood cutting, hunting and backcountry driving are activities which may be reduced by extensive logging. There is basically minimal recreational use in the area, but there is no quantitative measure of this.

3. Social and Economic

This analysis is directed to the Plan EIS, pages 111-14 through 111-17. The assessment includes communities not addressed in the Plan's social and economic analyses and was written with no coordination with the adjacent Forests which share the proposed haul zone and utilizes no concrete statistics. Coordination with Yellowstone National Park officials is also sketchy, especially considering that one of the alternatives considered in this Assessment is hauling timber through the northeast entrance of the Park, which would require an additional Environmental Assessment to be completed by the Park Service. 
Management of Forest uses that are of joint concern to Yellowstone National Park and the Forest are guided by joint committees which draft policies for these uses. One example is the effort that produced the Outfitter Guide Policy for the Greater Yellowstone Area. Others include creation and adoption of the guidelines for Management Involving Grizzly Bears in the Greater Yellowstone Area in 1979 and continued participation in the semi-annual meetings of the Greater Yellowstone Coordinating Committee, which consists of all area Forests and National Parks and Wildlife Refuges.

Additionally, the phrase "management of the forest plays a significant role in defining the fabric of the community and the reason many residents live there" is a prime example of the level of quantitative and qualitative data assessed and analysis completed for this Environmental Assessment (USDA Forest Service, 1989). Arising issues include the long term impact on the sawtimber industry in Cody, the "wearing off" effect of the '88 fires, ability to attract hunters, water quality and irrigation, and the ability of the Clarks Fork District to provide the recreational opportunities that are consumed by local residents. These issues are expressed as concerns but mitigation measures are notably absent. 
C. Promise or threat?: A study of "Greater Yellowstone ecosystem" management (Reynolds, 1987)

This book is an example of a key informant's assessment of the Shoshone Plan and management situation. The author is the president of the Wind River Multiple-Use Advocates and a member of Westerners Concerned About Resources and Environment (WeCARE) in addition to being an active recreationists, photographer, and assistant professor at Central Wyoming College in Riverton. Reynolds raises the following points:

1. The Forest Service should compare total income to number of jobs when comparing economic sectors (e.g. travel jobs are low-paying, seasonal jobs which represent $1 / 4$ of an oil or mining job and $1 / 3$ of a timber position).

2. He raises the key questions: Where are all the additional tourists going to come from? Where is the capital for additional facilities going to come from? Aren't service sector "replacement" and county-level analyses a gross overstatement of local level profiles?

3. No formal analysis of the combined impacts of the Shoshone and BridgerTeton Plans was undertaken. Again, he notes the use of questionable data for geographic analysis areas that aren't clearly defined. 
4. He recognizes the importance of local communities as gateways to the National Parks, but not primary gateways. He notes the fact that Park and Fremont Counties are not leading counties in terms of travel expenditures in the state.

5. He is concerned that Forest Plans intimidate the average citizen with their length and complication.

6. He expresses concern for the implications of adjacent Forests being managed by two different Regions of the Forest Service System (e.g. R2, which impements SRM, is in Wyoming and Colorado and R4, which doesn't, is in Montana, Idaho and Wyoming). Budgets, policies and directives can be quite different between Regions.

7. He believes the Greater Yellowstone's UNESCO Global Biosphere Reserve designation is unreasonable in that it requires a large core devoid of human activities. He theorizes that "it's wildest are not its own" (e.g. elk and bison populations). Chase (1986) supports this notion.

The seven concerns expressed are often the source of general public concern about Forest management direction. HRUs that include an active database of current community rather than aggregate county social and economic indicators and additional coordination between federal, state and local officials would 
most likely change the outcome of social assessment and subsequent mitigation measures.

\subsection{Conclusion}

This informal evaluation has raised issues about the use and need for accurate and current social and economic data and analyses. Use and development of HRUs in addition to agency guidelines for social assessment and public participation clearly needs to be addressed by agency planners. Changes in the management situation and the impacted planning area are clearly not expressed consistently in forest documentation and have not been officially updated since Plan development. 


\section{CHAPTER 7 \\ RECOMMENDATIONS AND CONCLUSIONS}

As detailed in the preceding Chapters, there is a general lack of consistency and clarity surrounding the Forest Service's implementation of mandated social analysis. The Socially Responsive Management program was adopted by the National Forests in the Rocky Mountain Region in order to meet the social analysis requirements outlined in Chapters 2 and 3. Implementation of prescribed SRM methods meets those requirements, although it was not developed solely for that purpose. HRU development and documentation is an integral part of SRM implementation at the local level.

The evaluation performed in Chapter 6 indicates that the success of SRM has been limited. Program objectives have not taken precedent in the Shoshone National Forest's planning process. Additionally, more explicit agency guidelines for the implementation of the National Environmental Policy Act and the completion of social and economic analyses have been established in the decade since SRM was adopted.

Specific problems with the application of HRUs as the base unit of the SRM program include the lack of updating and monitoring and lack of uniformity for comparison. The following recommendations are aimed at both social assessment in general and HRU documents. The basis for these recommendations lies in the conclusions drawn from preceding chapters, primarily Chapter 6. 
The Regional Forester should consider further implementation or termination of the SRM program in Region 2. Interdisciplinary team training in SRM techniques and re-assessment of forest goals are imperative for effective and responsive social assessment if the program is to continue.

As previously discussed in Chapter 3, alternatives to HRU's include a document called the Social and Economic Overview. If the Social and Economic Overview were developed and published in the Shoshone's Plan amendment process, it could easily be actively tiered to planning documents including projects and plans. Positive aspects of an Overview include: agency directives and guidelines (although vague), flexibility to encompass forestspecific goals and information needs, and diversity of components (e.g GIS mapping and comparison communities). Program guidelines for HRU development do not offer coordination of other information systems such as GIS.

\section{Information Systems}

As noted in Chapter 5, the development and maintenance of a substantial database for long-term resource planning, assessing the social and economic effects of various forest resource actions at a low cost, is imperative for comprehensive National Forest planning. In the past, the Shoshone has published a forest planning newsletter and/or a planning information pamphlet 
to distribute during the course of major planning efforts (USDA Forest Service, 1986).

These documents have alerted the public to the Forest's methodologies and the Forest's preferred management direction and essentially, resource trade-offs. Public information files and public participation forums provide the public with information, but the question of where does the Forest get its information often arises. The following group of three recommendations concentrate on the problem of information development in the Forest Service planning process.

\section{A. Public Information Officer}

The Forest needs to formally evaluate the need for and feasibility of hiring a Forest Information Officer. The Officer's duties, in addition to providing public information to interested parties, could include acting as a liaison between the forest and local, county, state, and federal agencies. Coordination of planning efforts between these various governmental levels is essential to rational and comprehensive planning.

\section{B. Socioeconomic database development}

A socioeconomic database should include information from various local, state and federal sources that, once integrated, will provide a valuable tool for the rapid retrieval, organization and analysis of information essential to timely and rational decision-making. If stored in the Forest Service's magnetic public 
file system, the information would be available as public record. Public knowledge of a more quantitative approach to socioeconomic analyses conducted in both project planning and the comprehensive planning process would not only improve the Forest's justification for its actions impacting local communities but the public response to those actions.

Potential applications of a systematic socioeconomic database include the following:

1. A descriptor of current conditions

2. A forecasting tool

3. A problem solving tool for hypothetical situations (considered in alternative development) that may arise in the future.

In addition, the database could be used to evaluate effects of legislation, for rapid information retrieval, and as environmental shopping list if other information is integrated such as watershed characteristics and areas of natural or historic value.

C. Development and use of an indicator program

Chapter 5 provides a discussion of goals, applications, and criteria for development and use of a social indicator system of evaluation to be used in social assessment. The integration of quantitative data and key informants could enhance the Forest's knowledge of its planning area and quality of social and economic analysis. Appendix E provides a potential list of data sources and key 
informant contacts for the Shoshone. Additionally, identified public issue areas might act as indicators of natural resource values.

Conversely, local and state governments might choose to include an assessment of Forest Service land management impacts in their planning processes. Impacts on local land use and community quality of life values are often very important considerations in communities adjacent to large tracts of public lands.

Other possible forums for interaction include annual or periodic meetings between agencies and/or the establishment of steering committees to coordinate information systems and planning efforts. Technical assistance may also be offered. Within the Forest Service, Regional and Washington Office personnel offer assistance in developing new programs and information systems.

\section{Conclusions}

Schweitzer (1984) offers the following expected benefits of the Forest Service's land and resource management planning:

1. Improve public access to information.

2. Improve dialogue among interest groups.

3. Give better information to managers.

4. Make explicit things never made explicit before.

5. Give a better idea of land suitability and capability.

6. Provide a mechanism for consistent agency data systems.

7. Require setting out a fuller range of alternatives. 
8. Require the forest to consider national needs.

9. Reduce resistance to change.

10. Lead to better land management.

11. Improve the balance among budgets for various uses.

12. Improve the coordination of federal and state planning.

13. Reduce litigation.

14. Increase professionalism.

Clearly, effective social analysis objectives should also strive to possess those characteristics. Although Forest planning is inherently complex, management of information systems and effective analysis techniques and documentation are essential to meeting mandates and responding to public concerns. 


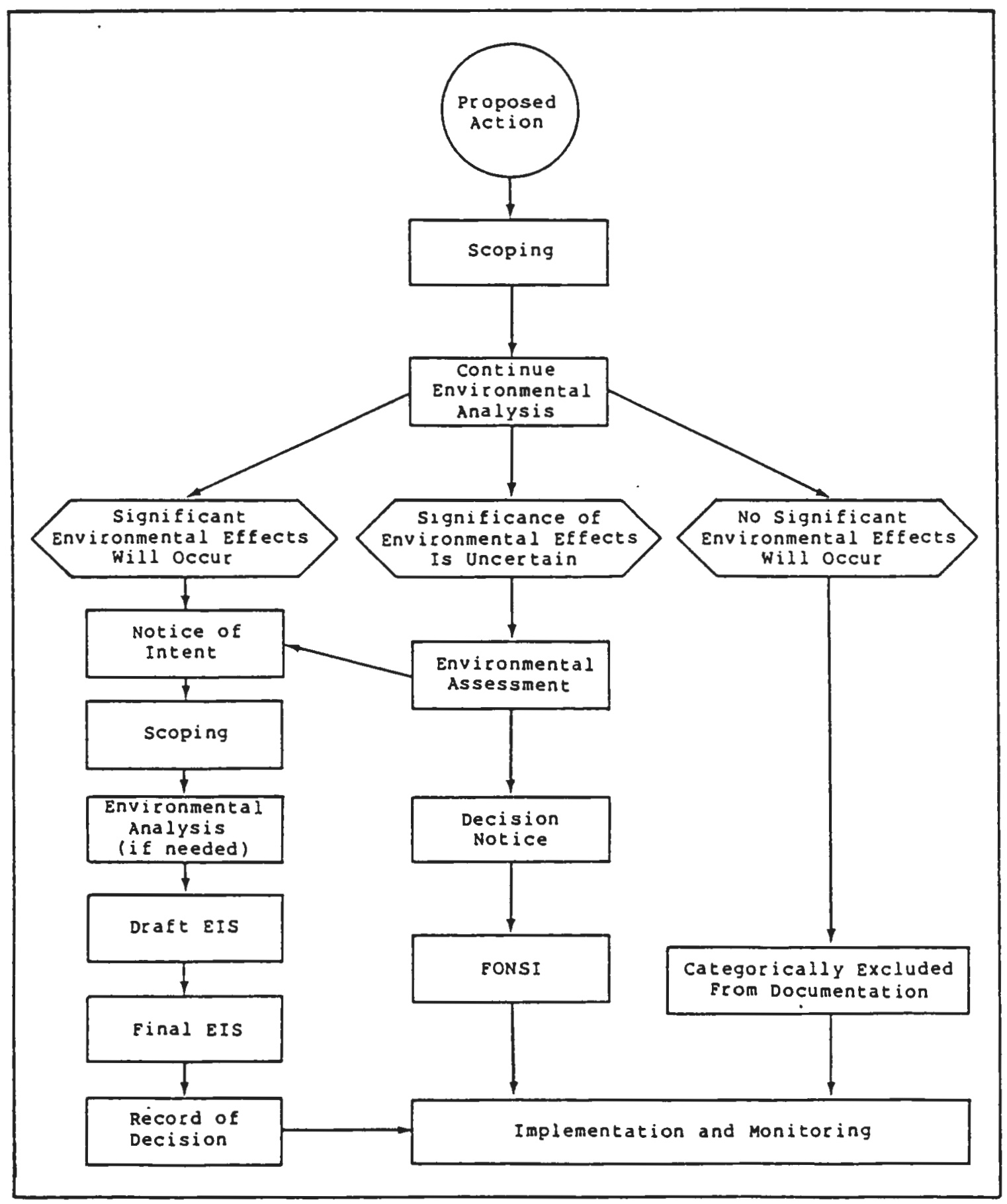




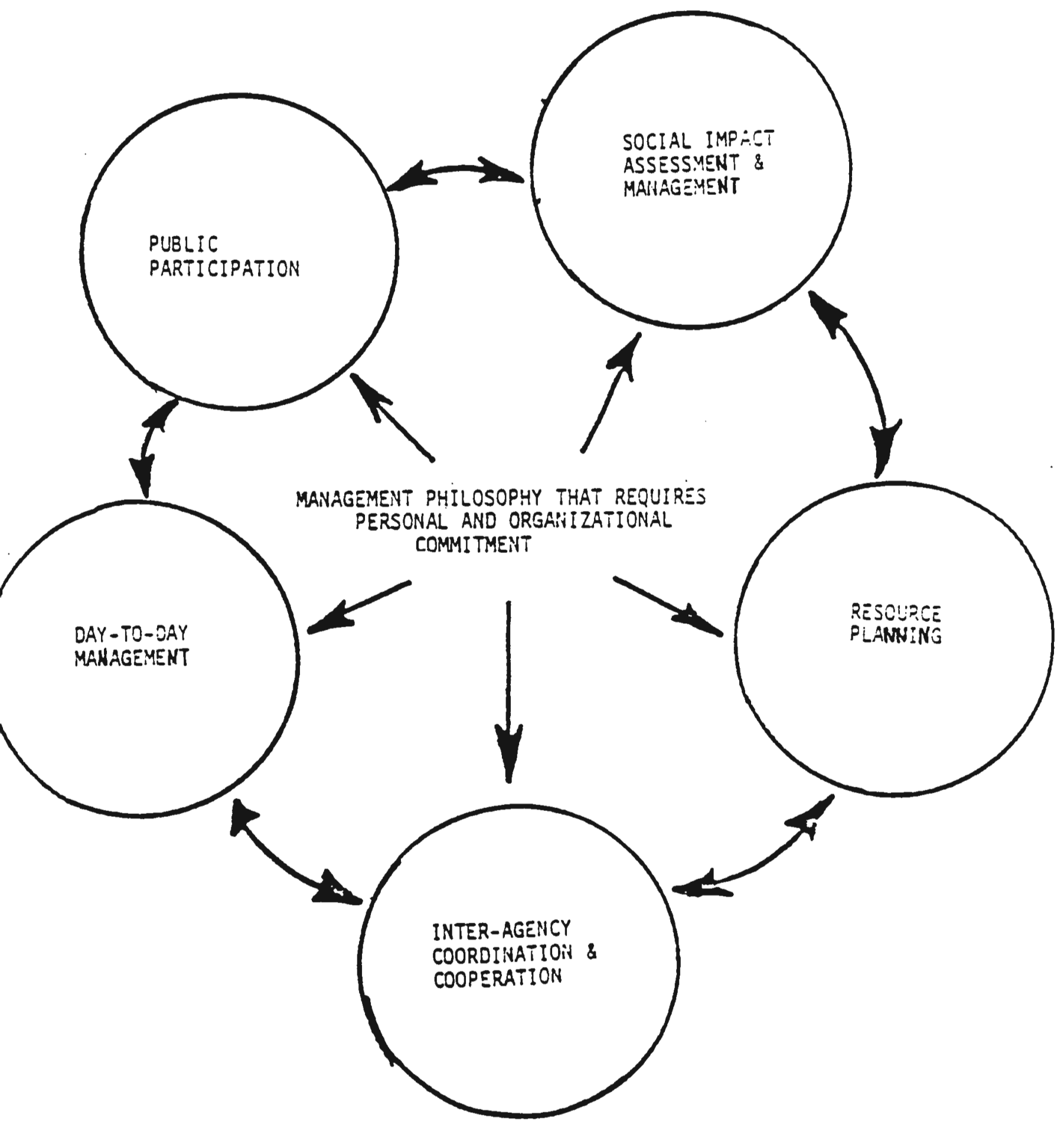

B-1 


\section{human resourte \\ unit example}

TONGUE - SHERIDAN HRU

NORTH CENTRAL WYMING

A Characterization of the Human Resource Unit

Using Cultural Descriptors

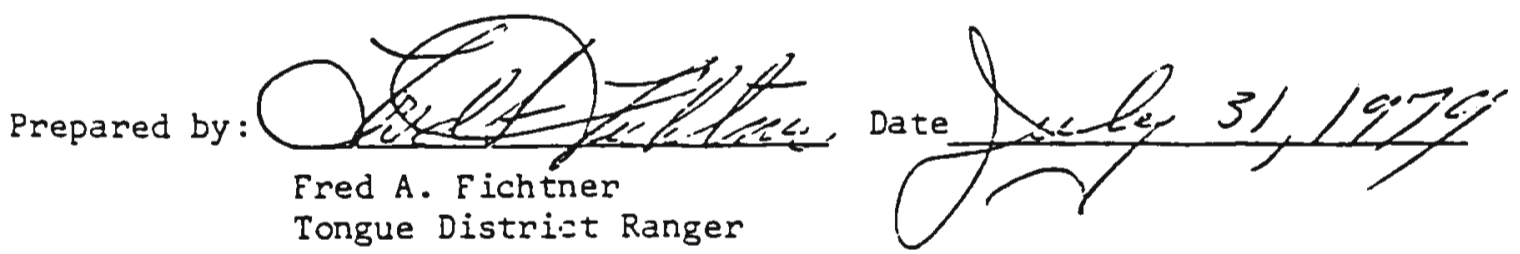


1. Forest Product Purchasers - Direct forest purchasers break naturally into two primary categories in this HRU--loggers and livestock producers. Both activities date back to the earliest settlement of non-Indian cultures here. The corporate influence is not strong in the livestock activity, although it accounts for most of the logging volume in the area, as indicated in the following tables:

\section{TIMBER PRODUCTION}

\begin{tabular}{|c|c|c|c|}
\hline CATEGORY & $\begin{array}{c}\text { NO. } \\
\text { PURCHASERS }\end{array}$ & $\begin{array}{l}\text { GROSS } \\
\text { CONTRACT VOLUME } \\
\text { UNDER CONTRACT }\end{array}$ & $\begin{array}{l}\% \text { OF } \\
\text { TOTAL } \\
\text { VOLUME } \\
\end{array}$ \\
\hline Independent* & 2 & $1.5 \mathrm{mmbf}$ & 23.3 \\
\hline Corporate & 1 & $4.93 \mathrm{mmbF}$ & 76.7 \\
\hline
\end{tabular}

*The independent category does not reflect the considerable amount of small timber sale business dorie each year on the Tongue District. The number of post and pole sales--largely to livestock producers--numbers in the hundreds. Also, each year the District puts up pole sales to native Anericans in the area for tepee pole use, and this activity draws from 100-200 purchasers. Finally, the taking of firewood from the Forest by local residents is very heavy, numbering in the thousands of users each year.

\section{RANGE PRODUCTION}

\begin{tabular}{|c|c|c|c|}
\hline CATEGORY & $\begin{array}{c}\text { NO. } \\
\text { PERMITTEES } \\
\end{array}$ & $\begin{array}{r}\text { GROSS ANIMAL } \\
\text { UNIT MONTHS } \\
\text { OF USE } \\
\end{array}$ & $\begin{array}{c}\% \text { OF } \\
\text { TOTAL } \\
\text { OWNERSHIP } \\
\end{array}$ \\
\hline Independent & 43 & 35 maum & 77.7 \\
\hline Corporate & 2 & 10 maum & 22.3 \\
\hline Independent* & 5 & 11.8 maum & 100.0 \\
\hline
\end{tabular}

*Indicates sheep operations under permit. 
2. Loggers and Related -- This is one of the major sources of employment directly related to the management of resources on the Forest. Wyoming Sawmill in Sheridan is the major operator within the HRU, reflecting the corporate figures listed under timber production in the Forest product purchasers discussion. In addition, this firm purchases an additional 7 to 10 mmbf yearly from private sources and the Bureau of Indian Affairs. There is a smaller post and pole treating plant and mill located in Sheridan and, as noted earlier, several smaller contractors purchasing posts and poles. It is estimated that there are 189 persons employed in timber harvest, hauling and milling in Sheridan County. The mills do have problems keeping and hiring employees due to the labor force demand and higher wages at the coal mines. This is a common problem, however, to all sectors of the economy.

3. Ranching-Agricuiture -- Ranching, in erfect, built.the state of Wyoming and was the mainspring of its economy for many years. It is still one of the three most important economic forces in Sheridan County, with mining and tourism close behind at this point. The National Forest has been an important source of grazing for many of these ranchers since before the Forest Service was even conceived, and continues to be critical to them today. Therefore, one finds the ranching community in the HRU knowledgeable in and concerned with management activities on the National Forest. Grazing permittees on the Forest range from onefamily operations to large, corporate operations involving thousands of acres in two states. Accurate breakdowns on employment in the agriculture sector are difficult to obtain, but a 1978 Sheridan Area Planning Agency report estimates that 37 per cent of Sheridan County residents earn their living in agriculture or agriculturerelated industries. Due to the dominant role of the industry statewide and locally for so many years, many ranchers in the immediate area are active and influential in the political scene, either holding offices or maintalning personal contract with elected officials.

4. New Residents -- This sector of the HRU may be basically defined as members of the population influx due to coal and coal-related activities, such as construction, etc. They represent an impact on the forest management picture in two ways. First is the simple weight of numbers growing rapidly in a very short period of time, which creates impact on all governmental services including those offered on the National Forest. Second is a lack of knowledge of or concern with Forest management activities and the responsibilfties of users of public lands. 
5. Classified Area Users -- This group is concentrated mainly in that section of Cloud Peak Primitive Area located within the HRU. Although numerically not nearly so great as some other sectors of Forest users, this group is relatively concentrated in an area of limited desirable camping spots, trails, etc. Protection of the resource and wilderness attributes of the area here will call for enhanced activity in the future. Basically, the group is divided into two sub-groups: the back-packers and foot travelers, and the users who travel the area by horseback. People who use the area are from the local, regional, and national level.

6. Hunters and Fisherpersons -- This is among the larger groups deriving direct benefits from forest resources through the deer and elk hunting season and summer fishing season. The group is a mixture of local people, touring publics and out-of-state users who come to the area annually for the opportunities. An increasing amount of use in this respect is coming from regional publics, particularly those living in Gillette and near the eastern Wyoming coal fields.

7. Touring Visftors, Campers and Picnickers -- Since the HRU lies along a major access route to Yellowstone National Park, this form of use attracts a considerable number of national and regional publics each year, although the numbers have waned somewhat with the energy problems. There are three basic sub-groups within this group:

Traveling public via Highways $14-14 \mathrm{~A}$, who will be found primarily in the developed campgrouncis along the highway, including Sibley Lake, Erune Creek, and Wwen Creek.

Local residents, who use the District in all areas, through both dispersed recreation and use of developed sites.

Annual Visitors -- This group returns to the Forest each year to take advantage of a wide range of recreational opportunities from developed campgrounds (particularly Dead Swede and Tie Flume) to dispersed recreation.

8. Summer Home Owners -- This public is comprised of those permittees who own homes within National Forest boundaries and also those who have summer homes adjacent to Forest boundaries and return to the area for 2-3 months a year are included. These seasonal residents tend to view the area as "their" Forest and often look with disfavor on the traveling publics using the resources in the area. 
9. Outfitters -- Although a smaller group numerically than others listed, this group is politically active and also active in Forest management activities. They range from small hunting operations to larger "dude" ranches which are among the oldest business establishments still functioning within the HRU.

10. Retirees -- The 1970 census figures indicate that approximately 25 percent of the HRU population is age 55 or older. It is safe to assume, however, that the influx of mine-related workers in the past nine years has changed that proportion considerably. Nonetheless, a substantial number of unit residents who use the Forest are retired federal employees, teachers, coal miners, railroaders and ranchers. As a group, they are very proprietory in their view of the Forest and management activities. Primary uses with this group are fishing, hunting, camping, picnicking, sightseeing and firewood gathering. Many members of this group also take part in the District's ánnual cone-gathering program.

11. Real Estate Developers, Brokers -- The recent coal-stimulated activity is reflected through the fact that there are now 26 real estate offices operating within the HRU. The market has been particularly active over the past four years, and a large portion of newly-developed lands are adjacent to Forest land. Within the urban sections of the unit, primary emphasis has been on development of mobile home parks and multi-unit rentals. There has also been considerable development activity, primarily of single-family dwellings, on what had been formerly ranching lands.

12. Non-Consumptive Forest Users -- This group contains members of other groups already listed and such formal groups as the Audobon Society, Wildlife Federation, etc. Their values and needs tend toward custodial resource management with minimum disturbance of the "natural" state.

13. Winter Recreators -- A growing number of local and regional publics are using recreational facilities and dispersed recreation opportunities during the winter months. Their activities include primarily snowmobiling, and cross-country skilng. 
14. Major Land Gwners -- Some 28 percent of the land in the HRU is federally owned, and 8.6 percent is owned by state and local government. The remainder, approximately 63.4 percent, is private, although more than 70 percent of mineral rights ownership is with state or federal government.

of the pirvate land, by far the largest part is held by ranchers and other agriculturists. Peter Kiewit Sons Mining and Burlington Northern Railroad are the largest private/industrial landholders in the HRU. Padlock Ranch, PK Ranch, Beckton Stock Farm, Denius Ranch and Allan 0 . Fordyce are the largest ranch owners in the area, according to the Sheridan County land ownership map.

15. Minorities -- A very small Mexican-American (less than 1\%) populace lives within the HRU and most live in Sheridan. One MexicanAmerican is a concrete contractor for the forest. No Indian publics live within the Tongue HRU, but they do purchase poles on the Forest. 
NETWORKS

\section{INFORMAL CITIZEN NETWORKS}

A. Rural Settlement Areas

1. Story Area:

a. Ranchers

This network consists mainly of those involved in cowcalf operations who depend on grazing permits from the Forest. The network is very active in town and Forest Service affairs and can be contacted at the Wagon Box or the Ladore Bar and Restaurant. Persons to contact are Deyo Jeffers, John Haniff, Winslow Taylor.

b. Conservationists

The network consists of people living locally and outside the area who stay in touch through their mutual interests and activities. They are active in Forest Service activities, especially the Cloud Peak Primitive Area. Mike Leon and Ben Roman are key contacts for this network.

c. Recreationists

This network is comprised of people who come from all over the country to recreate in the Story area in the summer and during hunting season. They are kept informed about local Forest Service activities through the manager of the Spear-0-Wigwam, which has a special use permit on the Forest. Archie MacCarty is the resort owner and key contact.

\section{Bighorn Area:}

a. Ranchers

Network of cow-calf operators who depend on Forest Service grazing permits. The netowrk has an ongoing interest in management policies and programs and can be contacted at Bozeman Trail Inn and the sale barn in Sheridan. Persons to contact include Victor Garber, Dr. Robert L. Connell, Ralph Knode, Andy Kukuchka.

b. Loggers

This network is involved in small family owned businesses incerested in post and pole cutting on the Forest. They also work part-time in larger sawlog operations in the area. Contact point is at Forest Service sale areas and at the mill in Sheridan. 
3. Ranchester Area:

a. Ranchers

The ranching network in this geographic area is larger in size and is involved in yearling operations. They depend on Forest Service permits to a much lesser degree, but are still active. Contact can be made at the Silver Spur and the Ranch House Restaurant. Persons to contact include Carl Kaufman, Don Johnson and Ike Carroll.

b. Tourists

Regional and national tourists frequently stop at the Ranch House Restaurant on their travels along Highway 14, which is the only major route through the Forest to points west like Yellowstone. Information about recreational opportunities and camping facilities are frequently discussed at this gathering place.

c. Land Developers

This growing network is interested in converting agricultural lands into residential developments, and many parcels are near or adjacent to Forest Service boundaries. They can be contacted through Ranchester State Bank. Key contacts include Jerry Doerr, Ike Carroll and Cap Rawlings.

d. Logging Industry

This network is interested in maintaining their only source of timber products off the Forest. Those involved in logging related activities can be contacted at the Bear Lodge, Blue Spruce, or Arrowhead Bar and Restaurant along Highway 14. A key person in the network is Don Cramer at the V.C. Johnston Lumber Company.

4. Dayton Area:

a. Ranchers

A combination of cow-calf and yearling operations are run in this geographic area and there are various degrees of dependency on grazing permits. This ranching network can be contacted at the sale barn in Sheridan and the Mountain Inn in Dayton. Persons to contact include Brad Spear, Art Badgett, Glen Sheeley, and Leonard Masters.

b. Logging Industry and Loggers

This network is interested in maintaining the-flow of timber products off the Forest to sustain their activities, but in recent years has lost some of its members to the mining industry because of higher wages offered. Contact points include the Bear Lodge, Blue Spruce and Arrowhead along Highway 14. Key contact is Stanley Olsen. 
c. Businessmen

This network is heavily dependent on the ranching and recreation businesses in the area, which rely for the most part on Forest Service land. They are very interested and active in the formulation of programs and plans. Key contacts are Don Roberts and Bill Switzer.

5. Parkman Area:

a. Ranchers

Combination yearling and cow-calf operations partially dependent on grazing permits are located here. James Niner, Kenneth Derns, LeRoy Dockery, Dave Fuller, and Fred Luth are persons to contact in this network.

6. Beckton Area:

a. Ranchers

More combination yearling and cow-calf operations which depend partially on grazing permits are located in this area. Key contact persons are Lambert Niedringhaus, Mrs. Waldo Forbes, and Joseph Fletcher.

7. Wolf Area:

a. Ranchers

Members of this network are involved in cow-calf operations and dude ranch resorts. Key contacts include Thomas Ferfuson, Frank Eaton, Charles Kane, Jr., and LeRoy Westman.

B. Urban Settlement Areas

1. Sheridan:

a. Ranchers

Most of the ranchers in this network are large landowners who are involved in yearling operations and who are becoming more and more interested in land development opportunities with the growing population in the area. Contact points are the Sheridan sale barn and the feed store. Persons to contact include Mrs. Waldo Forbes, Margery Masters, and Charles Kane.

b. Logging Industry and Loggers

The menbers of this network are interested in maintaining an even flow of sawlogs off the Forest. In recent years, they have had a dffficult time competing against mining wages and the level of production in the future is uncertain. Contacts are Ernie Schmidt at Wyoming Sawmills and Owen Sawyer at Sherida. : urest Products. 
c. Miners

These new residents in the area usually work together and socialize together. They enjoy the recreational opportunities on the Forest, especially 4WD, developed recreation, hunting and fishing. Mining networks can be contacted at Ritz Sporting Goods and Snack Shop, and the Pony Lounge.

d. Business and Professional

This network is comprised of local business owners who serve a wide variety of economic sectors. Businesses associated with recreational and ranching goods are especially interested in Forest Service programs and policies. Gathering places for business networks in town are Sheridan Center, Sheridan Inn, Brown Drug, XL Lounge, and Trail End Lounge. Persons to contact include Jackie Bly, Flo Upchurch, Evelyn Clark, Sam Mavrakis, Ray Johnston, Art Felker, John Patton, Charles Jorgenson, Marilyn Koester, William King, Dr. Jack Rhodes, Dr. James Batty, and Phil Oatts.

e. Summer Home Permitcees

This network is comprised of locals and some people from outside the immediate area who share the common activity of protecting their incerests on the Forest. Key contacts are Charles Rossa, W.E. Cook, Everett Berry.

f. Construction Workers

This network is made up of people who usually work and socialize together. Their interests on the Forest include dispersed and developed recreational activities. Contact points are Daylight Donuts and Big Daddy's

Disco. Key contact is "Doc" Holiday.

8. Recreators

Regional and national publics who use the Forest resources locally can be contacted through the Sheridan Information Center and Ritz Sporting Goods. Local recreators like snowmobilers gather at the Country Kitchen; backpackers and cross-country skiers at Ritz Sporting Goods.

h. Seniors

This network is comprised of retired ranchers and other local old timers who resent some of the changes occurring. They view the Forest as "theirs" and are very protective about their interests in resource programs and policies. Contact points include tie Post Office, Snack Shop, and Brown Drug. 
i. Youth

Local networks of young people function around school and social activities. School programs on the Forest are an interest and a good opportunity to inform them of Forest Service activities. Contact points are schools and Big Daddy's Disco.

j. Other Citizens

These people are in touch with multiple networks because of their personal activities and work; Gene McNair at the Post office, Silverio Rosalez at the butcher shop, and Charles Mitchell, a County road employee.

C. Regional and National Networks

1. Preservationists:

An informal network of people living on a regional and national level are tied together through the activities of Dave Fuller of Sheridan. They are preservation-oriented as well as multiple use advocates and are very involved in Forest Service program and policy development.

2. Recreators:

There is a very active network of people interested in the management activities in the Cloud Peak Primitive Area who stay in touch informally and return to the Forest annually for backpacking and other dispersed recreation activities. 
II. FORLAL URGANIZATIUNS, ASSGELATLUS, AND LLUBS

A. Lucal

1. Recreacional Clubs:

a. Bighorn Summer Home Protective Assoclation

(Charles Rossa, President)

This group is composed of sumner home permittees on the Forest. Members are, of course, concerned with management activities particularly as they relate to the status of their permits. Recently, a number of furmal appeals have been filed from this group in oppusition to announied increases in permit fees.

b. Trout Unlimited

(Dr. Charles Walter, President)

Although active in its uwn sphere, this group maintains a generally low profile. As might be expected, many of the members here will also be found in other organized recreation groups. Such issues as riparian grazing have drawn expressions of cuncern from this group on a national and regional level.

c. Ducks Unlimited

(Ralph Knode, President)

This group is similar to Trout Unlimfted, although dedicated to improving duck hunting opportunities. Many of the concerns, such as management of ripartan ecosystem, are common to the two groups. Again, many of the members here will also be found active in other organized recreation groups.

d. Sheridan County Sportsman Association (Tom Neighbors, President)

This organization has been active in the past over such issues as clear-cutting and sagebrush spraying. of late, tt has not been highly active, but remains a nucleus for expression and action should Furest management issues arise which are of concern to the sportsmen in the HRU:

e. Big Horn Mlountain Gun Club

(Rod Bisbee, President)

This group has nut been agressively active in Forest management issues recently, although any management activity affecting hunting and/or big game hubltat could be expected to draw a response from the membership, which is widespread and divorse. 


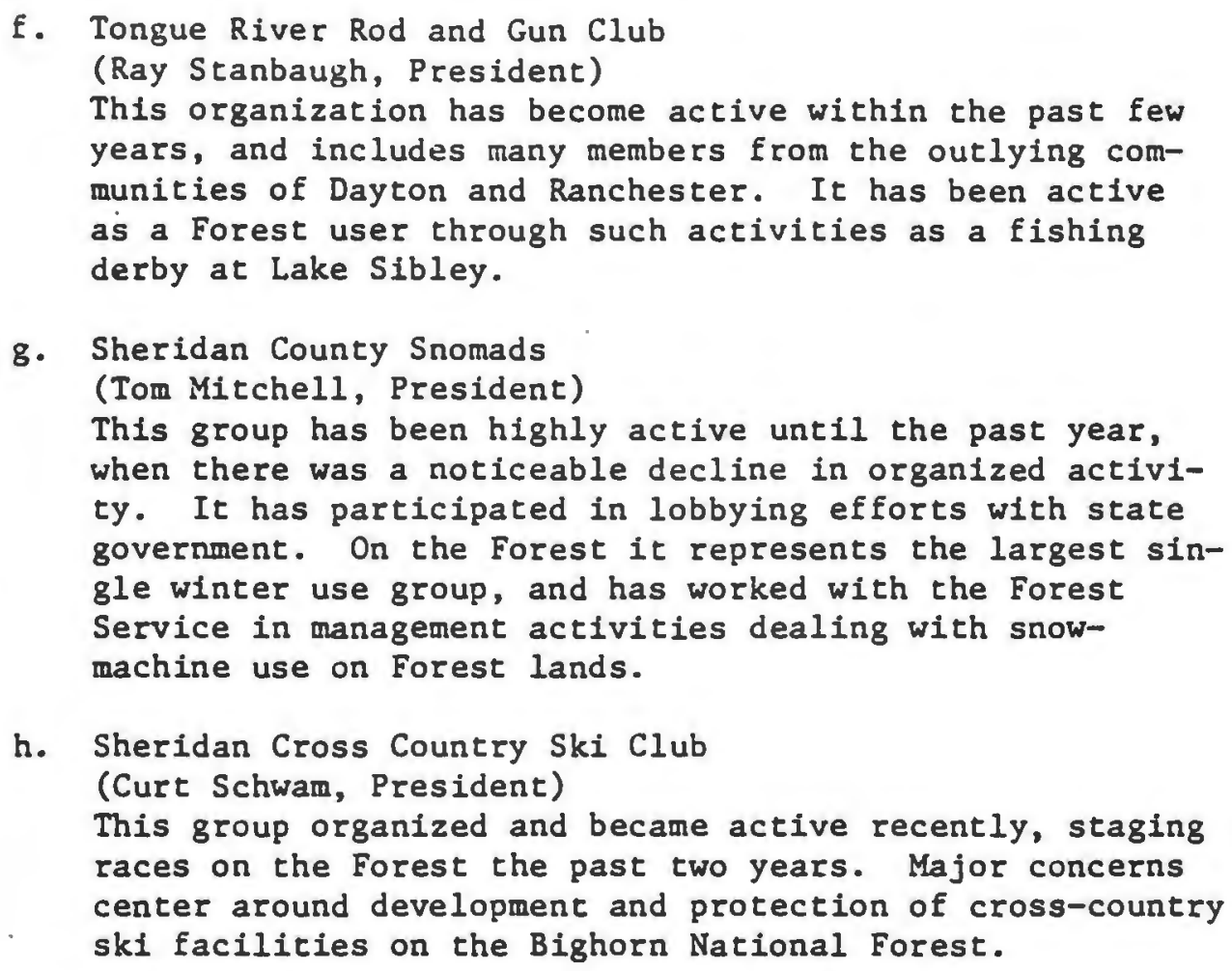

2. Ranching/Agricultural Organizations:
a. Wyoming Livestock Growers (Charles Kane, Dave Fuller, Leonard Masters)
b. Sheridan County Chapter, Farm Bureau (Bill Perkins)
c. Cowbelles (Margery Masters)
d. Bighorn Grazing Association (Glen Sheeley, Charles Kane)

3. Business/Professional Associations:
a. Lions Club of Story (Scott Ludwig)
b. Lions Club of Sheridan (George Meredith)
c. Kiwanis Club, Sherdan (Bob Wyatt)
d. Rotary Club, Sheridan (Bob Wilson)
e. Rotary Club, Dayton-Ranchester (Ray Johnston)
f. Sheridan Jaycees (Rick Thompson)
g. Business and Professional Women (Bonnie Wolff)
h. Blg Horn Lions Club (Ray Stroup)
1. Sheridan Councy Chamber of Commerce (Byron MacMillan) 
4. Youth Organizations:

a. Sheridan County 4-H Central Council (Ross Baker)

b. Boy Scouts of America (John Lansing)

c. Girl Scouts (Mrs. George Washut)

d. MMCA (George Leupold)

5. Governmental Bodies:

a. Local; County Commissioner (Mrs. Ruth Rice)

b. State; State Representative (Victor Garber)

c. Regional; Powder River Basin Resource Council (Sue Gates)

6. Service Organizations:

a. Army National Guard (Gene Ekroth)

b. Search and Rescue (Sheriff William Johnson)

c. R.S.V.P. (Paul Lindquest)

d. Sheridan Archaeologists (Margaret Powers)

e. Sheridan Historical Society (Glenn Sweem)

B. Regional and National

1. Preservationist Clubs:

a. Northern Wyoming Chapter Sierra Club (Tom Allen)

III. MEDIA SERVING AREA

A. Local

1. Newspapers:

a. Sheridan Press (Dick Redburn, managing editor; Milton Chilcott, publisher)

2. Newsletters:

a. Market Place (Ed Niehay, publisher)

3. Radio:

a. KWYO (Don Hargin, station manager)

b. KROE (Kim Love, general manager) 
B. Regional and National

1. Newspapers:

a. Billings Gazette (Linda Linu, Eastern Wyoming Bureau Chief)

b. Casper Star Tribune (Kathy Naugle, Sheridan)

2. Radio and Television:

a. KSGW, Channel 12 (Dave Staley, local operations, manager and newsman)

b. KTWO, Casper

c. KULR, Billings

d. KOTA, Rapid City 


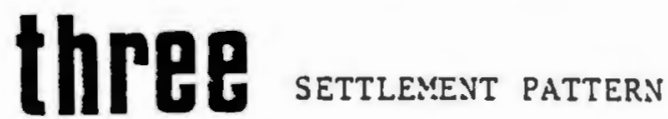

Earliest human settlement may date back as far as 10,000-12,000 years ago, when semi-permanent settlements were established by pre-Indian man. Traces remaining indicate fairly permanent settlements of this nature in the area.

Non-Indian settlement began in the late 1870's to $1880^{\prime}$ 's and were associated primarily at first with ranching activity. This was concurrent with and immediately following a period of considerable hostility between the Indian and non-Indian culture, including such incidents as the Fetterman Fight, Custer Fight, Dull Knife Battle, Sibley Scout Fight, Connor Fight, etc.

Early ranching settlements followed hard on the heels of these hostilities, although Fort McKenzie, now the Sheridan Veterans Administration Hospital," was established as a measure of protection for the northern Wyoming area.

Early settlement in Sheridan County was diverse, but primarily along the better ranchlands in the low country.

Among early settlers were members of nobility from England and Scotland, who contributed early to a cosmopolitan makeup which remains within the HRU. Also immediately ensuing were hostilities between large cattle ranchers and small ranchers, and between cattle ranchers, sheepmen, and farmers. Grazing began on a considerable scale at this time on what was to become, in 1903, a National Forest.

Sheridan at this time was not a major population center in northern Wyoming, both Buffalo and Big Horn having larger numbers of people. The decision to put the Northern Pacific railroad through Sheridan, however, decided it as the county seat. It further introduced a new industry to the Forest lands--tlmber. This was through the need on the part of the railroad for ties, and the industry lasted into the 20 th Century.

At the same time, prospectors began combing the Forest for gold, an activity which "flourished" for only a short period of time due to a lack of that mineral in paying quantity. Remains of the gold "rush" remain, as do many remains of the tie hack activity, including an impressive tie flume which stretched for nearly 30 miles from the sice of the tie hack activity to the community of Dayton.

At about the same time, intensive coal mining activity began on the lowlands in the unit, particularly along the Tongue River. Some thousands of people were employed in the underground mines, which caused such communities as Dietz, Kooi, Monarch, icme, and Kleenburn to be established. Mnst of the communities died when the demand for coal waned after World War II wich the advent of iesel locomotives on the railroad along with an increased use of electricity and natural gas for heating, cooling, ete. 
The only mine which survived this period is the Big Horn Coal Mine, which is still active in the county today under Peter Kiewit Sons Mining Division. The operation today, however, is a surface mining process, as opposed to the underground activity carried on during the earlier part of the century.

Sheridan suffered from outward migration in the 1950's and 1960's due primarily to lack of employment opportunities. This trend has completely reversed during the last decade because of the renewed interest in coal mining. Estimates obtained from Montana-Dakota Utilities and Spring Creek Coal for current population indicates nearly a 17 percent increase since the late 1960's in this area. Spring Creek Coal figures are as follows:

$\begin{array}{cc}\text { Year } & \text { Population Estimate } \\ 1969 & 18,100 \\ 1974 & 19,700 \\ 1978 & 23,500\end{array}$

Other indicators, such as bullding permits, have shown dramatic increases in the unit. Building permits issued in Sheridan in 1973 totaled 277, and estimated building expenditures were $\$ 3.5$ million. In 1978,678 building permits were issued, and the price tag was $\$ 13.5$ million. Total retail sales in Sheridan County increased more than $\$ 9$ million annually comparing 1978 with 1963.

In 1978, estimates calculated that $70 \%$ of the population in the HRU is urban. This changing settlement pattern is still accelerating today. The demand for single family housing is influencing the Forest Service, since many of the developments are occurring adjacent to Forest boundaries. Also, a noticeable change in settlement pattern is occurring within municipal areas, as apartments and mobile home courts for rental purposes are beginning to boom.

Currently, all communities in the HRU are increasing in population. The most dramatic increase is in Ranchester, which has gone from slightly more than 100 just prior to 1970 to an estimated 400-500 today. 
Mining and mineral-related activity, government of all levels, and agriculture/agriculture-related activities are the three most predominant economic sectors in the HRU.

During the last decade, the coal boom has been the most significant factor in changing the work routines in the HRU. For the msot part, the coal is extracted by strip mining and many people have been hired locally. Also, companies have attracted many newcomers to the HRU to work in a rapidly growing 1ndustry. Present mines in operation include Decker East and West--the largest surface coal operation in the world; Big Horn Coal; Black Mountain Coal; Spring Creek Coal; and some smaller mines, with at least two larger mines proposed to begin within the next two years.

Historically, the coal has been used regionally by the Montana Dakota Utilities power plant. The increase in mine openings and production is generating a resource that is now exported nationally.

The second major employer is government, with most of the jobs associated with the Veterans Administration, Forest Service, Soil Conservation Service, Sheridan County, and the City of Sheridan. Together they account for $24.65 \%$ of the work force.

Ranching provides the major source of employment in the agricultural sector, which is now third in the HRU. Forest Service programs most directly relate to this economic activity, since many ranches depend on grazing permits to round out their yearling operations. Some ranchers are completely dependent and have cow-calf operations that require permits on the Forest seasonally.

Other employment generated by Forest products include jobs in logging and, to a smaller extent, recreation. Recreation employment is generally through the three small resorts and other recreation-related businesses located within ghe HRU. Services like motels, restaurants, sporting goods, taverns, and others obtain a certain portion of their income from business during the summer tourist and fall hunting season. Other seasonal employment comes from construction, some logging, agriculture-related work, and local government. Although the federal government at one time provided a work market for local young people, current selection procedures have sharply limited that practice. Burlington Northern Railroad provides some summer jobs, but is not the major factor in the labor market it once was. 
I. Formal Support Services

\section{A. Protective}

Fire protection services are centered in Sheridan, although there are rural fire districts throughout the HRU. Ranchester, Big Horn, Dayton, and Story also have rural volunteer fire departments. There is a high degree of cooperation between these organizations and Forest Service fire control programs. Law enforcement is also centered in Sheridan, with the County Sheriff considered the chief law enforcement officer in the county. However, Sheridan County has the lowest number of police personnel per 1,000 population of any county in Wyoming. Urban law enforcement in Sheridan is under a chief of police and administered under the mayor-council form of government. Ranchester and Dayton have town marshálls and will have deputy sheriffs in the near future. The County Sheriff and Forest Service work under a cooperative law enforcement agreement, and have enjoyed close cooperation in past years. The Sheriff's office coordinates all search and rescue activities. Primary ambulance service is maintained in the City of Sheridan, with volunteer ambulance service originating from Story and Dayton. All services, but most particularly law enforcement, have been considerably strained within recent years due to problems engendered by the number and characteristics of much of the population growth in the HRU. Although not on as large a scale at this time, the problems are identical to those experienced by other communities such as Gillette and Rock Springs during rapid growth periods.

B. Medical

Medical services are located in the City of Sheridan, primarily in Memorial Hospital of Sheridan County. Related professional services are situated almost entirely in the City of Sheridan. Emergency communications are via telephone, citizen band, or through a newly formed amateur (HAM) radio operator's group. REACT, a local group of CB volunteers, monitors Channel 9 on a 24-hour basis.

C. Municipal

City and town services have been under stress in recent years with the population increases associated with mining activities. Local government is in serious difficulty trying to keep up with the demands for improved services because there is an inadequate supportive tax base. The problem is caused by numerous miners who live just across the state line in the northern portion of the HRU. A majority of the newcomers work in Montana and live in Sheridan and surrounding communities. This situation has created a sense of antagonism between many of ... is long-time residents and the newly arrived population because growth has not paid its own way. 


\section{Commercial}

Commercial services of a wide variety are centered in Sheridan, although such services are found in nearly every community within the HRU. Billings, Montana, 130 miles away, and Casper, Wyoming, 150 miles away, are popular shopping areas for HRU residents making major purchases. On the other hand, Sheridan draws a shopping public from Gillette, 104 miles away; Buffalo, 36 miles away; and many of the smaller southern Montana communities as far distant as 70 miles. Many of these shoppers are also seeking medical services in Sheridan.

E. Community, Church and Volunteer

Every community within the HRU has at least one civic club, but the majority are located in Sheridan. These include Lions, Kiwanis, Rotary, Jaycees, and such fraternal orders as Elks, Moose, Eagles, Odd Fellows, Mason, Shrine Club, etc. There are also several very active women's groups in the area, including Business and Professional Women, Sheridan Civic League, League of Women Voters, Daughters of the American Revolution, Daughters of the Nile, Big Horn Women's Club, Story Women's Club, and a number of sororities. Also active within the community is RSVP, an organization of senior citiaens, as well as several organizations for retired persons. The Sheridan Chamber of Commerce also plays an active role in the community.

The HRU has a large number of churches with numerous and diverse denominations with many active members. One of the more important community organizations in the HRU is the YMCA, which provides educational and recreational activities for all ages.

All the community organizations provide valuable services to the people of the area. The vitality of local church and civic organizations add an important characteristic to the HRU. Over the years, these service organizations have been natural avenues for working with people on a wide variety of Forest Service management programs and activities.

\section{INFORMAL SUPPORT ACTIVITIES}

Most informal caretaking is done through a system that includes the members of church congregations, neighbors, and extended family networks. Senior citizens are very active in taking care of each other and organizing recreational activities.

A few long-term residents of Sheridan have moved into the newer subdivisions built in Sheridan. They have organized block parties so that the newcomers and the older residents can meet one another. At these parties all the residents i an entire block will get together for a picnic at one house. This has been an effective way of integrating the newcomers into the community. 


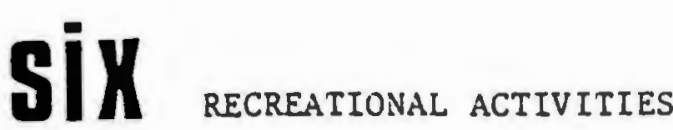

The Forest is the hub of recreational activity for many of the residents throughout the unit, providing fishing, hunting, camping, sightseeing, bird-watching, rock-climbing, backpacking, horseback riding, trail riding, skiing, snowmachining, snowshoeing, and a variety of recreational opportunities. Considered as a major drawing point in attracting new residents to the area, the Forest soon becomes an important factor in the life style of the majority of residents within the HRU.

In recent years, the Forest Service has had a difficult time managing the increased number of local users. Demands are especially great on developed facilities and roads with the increase in $4 \mathrm{WD}$ activities. Some conflicts are starting to occur between recreation and other resource programs like grazing and wildife management. Also, the characteristics of some new users are creating problems and law enforcement measures have sometimes been required to deal with vandalism; poaching, and road closure restrictions.

Numerous regicnal and national publics also use the Forest resources locally, especially during hunting season, for sumer recreational activities, and for sightseeing and camping when traveling through the area.

Off the Forest, the center of activity is undoubtedly the local YMCA, whicis provides a full range of activities--swiming, tennis, racket ball, handball, basketball, arts, crafts, dancing, etc. The YMCA is something of a focal point for social activities. A newly developed City-County recreation program, which includes swimning, baseball, softball, and gymnastics, has become very popular in the past two years. In addition, many parents are very active in school sports programs. 
The rural agricultural characteristics of the land are rapidly changing with the rejuvenation of coal mining. The population associated with the growth likes to settle in the open space lands around Sheridan, Ranc'tester, and Dayton where they are close to municipal services and Forest Service recreational opportunfties. The popularity of the area is reflected in the property values that have increased as much as $300 \%$ in the last decade. The traditional social structure and land use patterns on private and public lands are under stress in the HRU. Long-time residents and newcomers sometimes find themselves in disagreement on what kind of future they want for the area.

The HRU is tied together by the interaction of publics, their networks, work routines, support services, and recreational activities. The changing settlement in the area has changed the HRU boundaries recently to include the coal mining region just across the state line in southern Montana.

The eastern boundary is a line nearly parallel with Interstate 90 , and approximately 15 miles east of the community of Sheridan. Distance, sparse population, and lack of access are characteristics which break this HRU on the east from the Gillette, Wyoming, area, although we do receive some social, economic, political, and cultural interaction from the Gillette area.

The northern boundary follows the Montana-Wyoming state line except for the Deckers, Montana, area, which is in the Tongue HRU. The unit is also subject to considerable social, economic, political, and cultural interaction from the southern Montana area.

The western boundary of the Tongue HRU follows the ridge of the Big Horn Mountains and includes the portion of the Cloud Peak Primitive Area that gets use from the Tongue District. This boundary runs northwest to the Montana state line.

The southern boundary follows closely the boundary lines of the Tongue and Buffalo ranger districts, extending eastward just north of Lake DeSmet until it joins the eastern boundary. The town of Story is on the southernmost boundary of the Tongue HRU. It relates north to Sheridan. Everything south of Story--people, shopping, services, recreation--relates to Buffalo. 


\section{summary}

\section{TRENDS INFLUENCING THE CURRENT SITUATION}

A. Ranching (Within Forest Boundary)

Ranching has remained stable, for the most part, within the Forest boundary in the HRU, originating primarily with the family ranch units. Growing industrial demands for water and land for development will affect the Forest directly in increasing the importance of the grazing resource within the unit. Grazing of domestic livestock on the Forest has also come under question from some of the new population entering the area, and may become a question of a political nature within the near future as values and attitudes of the new publics change as to resource use.

B. Mining

No minerals of real value have ever been extracted from the Forest, and mining to any real extent does not exist within the District. Coal mines within and adjacent to the HRU have exerted an impact on the Forest, which has been discussed in the appropriate sections of this document. Primary impact is in both dispersed and developed recreation programs.

C. Logging

The impact of coal mining in the area has exerted an impact on this industry in the sense that it is becoming increasingly difficult for local logging operations to attract and keep laborers and equipment operators. The relatively high salaries offered by the coal mines have placed a labor stress on the operations. Another economic impact came through the recent RARE II process. Establishing large tracts of areas for further study, in effect, precludes logging activity for years to come, and is viewed by representatives of this industry as harshly detrimental to their future on the Forest.

\section{Private Recreation Development, Including Resorts}

With the exception of large motels located in the urban area of the unit, there are no private recreation developments of a major nature in the HRU. Overnight trailer and mobile unit parks are located in Sheridan, Ranchester, and Dayton. Blue Spruce, Arrowhead, and Bear Lodge on the Forest are privately developed recreation resorts, the latter two under special use permit with the Forest Service. Srear-0-Wigwam operates on the Forest as a resort area, and the Eaton Ranch operates adjacent to the Forest boundary, but makes extensive use of the Forest during the "dude" season. Incentives will be needed for private industry to meet some of the growing recreation tomands in the area, or the Forest Service will have to supply tll: hervices. 


\section{E. Government Services}

Studies over the past decade have pointed to shortcomings in the abilities of local government to meet denands from the increased population. The most obvious problem is the fact that most of the population works in mines or mine-related industry located outside the tax boundaries of local government units. This creates the classic "bedroom community" situation, leaving the sales tax as the only revenue source within the County. Sales tax income is currently not increasing East enough to cover the expenses of a growing population. The fact that an optional one percent increase in that tax failed once and then passed the electorate only narrowly was regarded by many as a demonstration of reluctance among long-time residents to support the population influx. Local government also experiences the common problem of attracting and keeping good help in the face of salary competition form the mines; i.e., a newly opened mine recently attracted away from city government both the police and fire chiefs. The Forest Service might find itself in the same situation in the near future.

Problems also extend directly into the Forest and Forest Service. One of the most immediately apparent problems is the type of user encountered among the new residents of the HRU. Most have fourwheel-drive vehicles, and are either entirely lacking in knowledge or are unconcerned with resource protection measures instituted by the Forest Service. Similarly, such undesirable use patterns as litter, abandoned campires, vandalism, and destruction of property have shown a discernible increase. These trends, along with more intense use, will require new action and thinking in the area of resource protection.

Management responses may take several different directions--from a more intensified approach to enforcement of regulations to a stepped-up public education campaign. Whatever solutions are attempted, the Forest Service should attempt to cooperatively address the common problems facing the service organizations in the HRU. 


\section{APPENDIX D \\ DATA SOURCES FOR SOCIAL IMPACT ANALYSIS}

I. Bureau of Census Publications

A. Census of Population

1. area and population size

2. urban population proportion

3. labor force composition

4. productivity of the population

5. extreme incomes (quartiles)

6. educational attainment

7. in and out migration

B. Census of Housing

1. dwelling condition

2. household modernity

3. owner-occupied homes

C. Census of Agriculture

1. value of farm products sold

2. average farm size

3. agriculture tenure classes

D. Census of Business and Industry

1. per capita retail sales

2. economic complexity

3. unemployment rate

4. government complexity

II. State records
A. Marriage rate
B. Birth rate
C. Death rate
D. School attendance records
E. Public assistance payments
F. Local educational expenditures
G. Permits for resource or mineral removal
H. Reported criminal activity

III. Private records and reports
A. Per capita disposable income
B. Median family income
C. Bank receipts 
IV. County and other local records
A. Improved local highways
B. Record of deed transfers
C. Value of real property
D. Per capita local expenditure for education
E. Land-use patterns
F. County relief expenditures
G. Other Measures

V. State and federal agency reports
A. Cooperative extension service
B. Soil conservation Service
C. Farmer's home Administration
D. Department of Health, Education and Welfare

VI. Archive Information
A. Newspaper Reports
B. Official transcripts of public hearings
C. Cost-benefit analyses of present and proposed projects

VII. Data from personal interviews
A. Personal and family background variables
B. Socioeconomic statistics
C. Attachment to place and ancestral ties
D. Identification with the community
E. Previous occupational and geographic mobility
F. Attitudes toward and knowledge of resource development and development in general
G. Quality of individual and family life
H. Participation in public decisionmaking
I. Institutional variables

Source: Jain and Hutchings, 1974 


\section{APPENDIX E \\ HRU DESIGN AND SOURCES}

\section{A. Potentially Relevant Social Variables}

Activity Patterns:

Community/Association involvement

Land uses

$$
\begin{aligned}
& \text { commercial } \\
& \text { industrial } \\
& \text { institutional } \\
& \text { public } \\
& \text { residential } \\
& \text { transportation/utilities }
\end{aligned}
$$

Recreation (facilities, participation)

Transportation (public/private)

Population characteristics:

Age, race, sex

Density/distribution

Education/race/sex

Fertility

Income/race/sex

Marital status

Migration

Mortality

Urbanization

Public Services:

Educational

Fire

Health (medical/mental)

Police

Welfare/unemployment

Social Psychological:

Attitudes/opinions 
Social Strata:

Education achievement

Household composition

Housing by type/age/size

Housing by value/rent/vacancies

Income by employment

Income by size/type of family

Labor force characteristics

Occupation of employed persons

Unique Historical, Cultural and Natural Landmarks

B. District Input (Identification of Management Concerns)

1. Standard Inquiries:

a. identify uses/publics

b. permittees - range and timber

c. special uses - outfitters, lessees, pipelines, etc.

d. developed use area surveys - picnic areas, campgrounds, roads, trails, ski areas

e. changes in land uses (e.g. rights of way)

f. demand for resources - water, minerals, gravel, road construction materials

g. present and future projects that might have a significant impact on use and perception of management

h. personal goals (in addition to Forest goals)

i. key informants/contacts

2. District-Specific Issues:

a. Clark's Fork

i. Road development - Dead Indian

ii. qualities of visuals due to ' 88 fire season

b. Wapiti

i. real estate market condition

ii. North Fork Highway EIS and re-construction

iii. grizzly bear Situation I

iv. Sleeping Giant Ski Area management

v. impacts of Husky Oil pullout

vi. irrigation projects and the raising of the Buffalo Bill Dam

vii. Park impacts on tourism

c. Lander

i. Ghost Towns - Miner's Delight, Atlantic City, South Pass

City

ii. new "visitor's center" 
iii. Reservation politics

iv. Indian claims on Big Horn River

v. U.S. Steel - Riverton/Lander

vi. industrial exodus

d. Greybull

i. access to Forest lands/lack of roads

ii. Exxon EIS for exploration on Carter Mountain

iii. minerals exploration

iv. Grass Creek right of way acquisition

e. Wind River

i. grizzly bear Situation V/I

ii. demand for wood products - Louisianna

Pacific pullout of Duvois and Riverton

iii. renewal of the Upper Wind River Valley

iv. state of the Dunoir Special Wilderness Area 


\section{Key Informants}

Cody Economic Development Council 836 Sheridan Avenue

P.O. Box 2777E

Cody, WY 82414

$587-2639$ or $587-2297$

Key:

Powell Valley Chamber of Commerce 111 S. Day

Powell, WY 82435

Key:

Park County Historical

Archives Ctr.

1002 Sheridan Ave.

Cody, WY 82414

587-2204

Key:

BLM Cody Resource Area Office 1714 Stampede Ave.

P.O. Box 518

Cody, WY 82414

Key: Tom Enwright, Kathy Mufich

Cody Lumber

P.O. Box 757

Cody, WY 82414

Key: Mike Hansen
Cody Country Chamber of Commerce 836 Sheridan Avenue

Cody, WY 82414

587-2297

Key:

Marathon Oil

P.O. Box 2690

1501 Stampede Ave.

Cody, WY 82414

587-4961

Key: Pat Childers (x4961) 7-25-89

Nielson Enterprises

1825 Big Horn Avenue

Cody, WY 82414

587-4291

Key:

Rep. Bill Rohrbach 7-26-89

Wyoming Outfitter Association

1809 Mountain Road

Cody, WY 82414

Key:

Foundation for N. American Sheep 720 Allen Avenue

Cody, WY 82414

Key: received information 
Park County Planning and Zoning

Park County Courthouse

Sheridan Ave.

Cody, WY 82414

587-2204

Key: Tim Morrison, County Planner

Northwest College

$231 \mathrm{~W} 6$ th

Powell, WY 82435

$1-800-442-2946$ or $754-6111$

Key:

Thermopolis Chamber of Commerce

Hot Springs County Government

Hot Springs County Courthouse

Thermopolis, WY 83443

864-2732

Key: Lee Nellis, County Planner

State Senator Hank Coe

32 Road 3cx-s

Cody, WY 82414

Key:

State Rep. Peg Shreve

1120 Meadow Lane

P.O. Box 2257

Cody, WY 82414

Key:

Fremont County Assoc. of Govt's

P.O. Box 1700

Riverton, WY 82501

$856-8589$ or $332-2870$

Key: Earl Mathers, County Development Dir.
Senator Alan Simpson's Office

1731 Sheridan Avenue

P.O. Box 430

Cody, WY 82414

527-7121

Key: Nancy Shaw

Northwest Wyoming Resource Council 1102 Alger

Cody, WY 82414

Key:

Powell Aviation

Powell Aviation

Powell, WY 82435

754-5234

Key:

State Rep. John DeWitt

440 E. 8th Street

Powell, WY 82435

Key:

Wyoming State Journal

267 Main

Lander, WY 82520

332-2323

Key:

National Outdoor Leadership School

Box AA

288 Main

Lander, WY 82520

Key: 
Wyoming Wood Products

Route 63

Box 471

Lander, WY 82520

Key:

State Rep. Frank Dusl

600 Fremont St.

Lander, WY 82520

Key:

State Rep. Mary Odde

621 California

P.O. Box 236

Shoshoni, WY 82649

Key:

State Rep. Dennis Tippits 1614 Gannet Drive

Riverton, WY 82501

Key:

Dubois Town Government 712 Meckem Steet

Dubois, WY 82513 455-2345

Key: Pat Neary, Town Admin.

State Senator John Vinich 217 South Main

Box 67

Hudson, WY 82515

Key:
State Rep. Harry B. Tipton, M.D.

745 Buena Vista

Lander, WY 82520

Key:

State Rep.

P.O. Box 112

Riverton, WY 82501

Key:

State Rep. Scott Ratcliffe

27 Old Mule Drive

Riverton, WY 82501

Key:

Wyoming Outdoor Council

P.O. Box 1449

Lander, WY 82520

332-7031

Key: Cat Ulbright, Field Director

Dr. John Murdock

P.O. Box 397

Dubois, WY 82513

Key:

Red Lodge Chamber of Commerce 601 N. Broadway Avenue Red Lodge, Montana 59068 (406)446-1905 - Library Key: 
Carbon County Planning Director 206 N. Broadway Ave.

Red Lodge, MT 59068

(406)446-1694

Key:

Town of Cooke City

P.O. Box 1146

Cooke City, MT 59020

(406) $838-2272$

Key:

Tribal Complex Information

Tribal Resource Specialist

Shoshone Oil and Gas Commission

15 North Fork Road

Fort Washakie, WY 82514

Key:

Survey Research Center

University Station

P.O. Box 3925

Laramie, WY 82071

766-2931

Key: Terry Haven

Wyoming Game and Fish Department 260 Buena Vista

Lander, WY 82520

$1-800-654-1178$

Key:

Robert Fletcher

Department of Agricultural Economics

P.O. Box 3354

Laramie, WY 82071

766-3373

Key: Extension Specialist
Carbon County Commissioners

601 N. Broadway Ave.

Red Lodge, MT 59068

(406)446-1595

Key:

Bureau of Indian Affairs

Wind River Agency

Superintendent Administrative Officer

Lander, WY 82520

Key:

Northern Arapahoe Business Council 509 Ethete Road

Lander, WY 82520

Key:

Wind River Multiple-Use Advocates

1210 Mary Ann Drive

Riverton, WY 82501

Key: George Reynolds

WY Economic Development and Stabilization Board

Cheyenne, WY

774-7284 or $777-6431$

Key: Steve Achter

Rocky Mountain Oil and Gas

951 Werner Court

Suite 100

Casper, WY 82601

Key: 
State Planning Coordinator's Office 2320 Capital Ave.

Cheyenne, WY 82002 777-7574

Key: Richard Miller

Wyoming Wool Growers Association 811 North Glenn Road

Casper, WY 82601

Key:

Greater Yellowstone Coalition

P.O. Box 1874

Bozeman, MT 59715

(406)586-1593

Key: Louisa Wilcox or Dennis Glick

Foundation for Urban and Neighborhood Dev. (FUND)

2653 W. 32nd Ave.

Denver, CO 80211

(303)433-7163

Key: Richard Griewe

Wyoming Stockgrowers

113 E. 20th

Cheyenne, WY 82001

Key:

Montana Division of Vital Records

(406) $444-2614$

Key:
Wyoming Public Lands Council

P.O. Box 115

Casper, WY 82601

Key:

Wyoming Centennial Commission

Cheyenne, WY 82002

$1-800-442-4333$ or $777-5844$

Key:

Sierra Club

23 N. Scott

Sheridan, WY

Key: Larry Melhaff

Senator Wallop's Office

P.O. Box 1014

Lander, WY 82520

Key: Pam Redfield

Wyoming Department of Highways $777-4190$

Key: Addie Urich (traffic counts)
Billings Gazette

P.O. Box 821

Cody, WY 82414

Key: 
Carbon County News

P.O. Box 970

Red Lodge, MT 59068

Key:

Powell Tribune

74 Rd. 2 EC

Cody, WY 82414

Key:

Institute for Policy Research

University Station, Box 3925

Laramie, WY 82071

766-5141

Key: Wyoming Quarterly Update

Forest Supervisior

GYCC Team Leader

Custer National Forest

Box 5556

Billings, MT 59103

(406)657-6361

Key:

Superintendent

Grand Teton National Park

P.O. Drawer 170

Moose, WY 83012

733-2880

Key:
Cody Enterprise

1549 Sheridan Ave.

Cody, WY 82414

Key:

Riverton Ranger

Box 993

Riverton, WY 82501

Key:

Bridger-Teton National Forest

340 N. Cache

P.O. Box 1888

Jackson, WY 83001

733-2752

Key:

Forest Supervisor

Gallatin National Forest

P.O. Box 130

Bozeman, MT 59715

(406)587-6701

Key:

Superintendent

Yellowstone National Park

P.O. Box 168

Yellowstone Nat. Park, WY 82190

344-7381

Key: 


\section{Data Sources}

\section{Wyoming - Background}

Edgerly, Len. 1983. Economic diversification: A Wyoming alternative. Cody, WY: Wyoming Heritage Foundation.

Glasner, David. 1985. Politics, prices, and petroleum: The political economy of energy. San Francisco: Pacific Institute for Public Policy Research.

Institute for Policy Research. 1989. Wyoming Quarterly Update 8.

Rand McNally. 1989. Commercial atlas and marketing guide. New York: Rand McNally and Co.

Siddayao, Corazon Morales. 1986. Energy demand and economic growth: Measurement and conceptual issues in policy analysis. Boulder, CO: Westview Press.

SRI International. 1985. Building a stronger Wyoming: Opportunities in a troubled economy. Cheyenne: Wyoming EDSB.

U.S. Department of Commerce. 1986. County Business Patterns. Washington, D.C.: GPO.

U.S. Department of Commerce. 1988. City and County Data Book. Washington, D.C.: GPO.

U.S. Department of Commerce. 1989. Statistical abstract of the U.S. Washington, D.C.: GPO.

U.S. Senate, Committee on Small Business. 1987. Small business problems in Wyoming related to the energy industry. Washington, D.C.: GPO.

-.-..- 1988. The economic impact of fires in Yellowstone National Park and Western Montana on small business. Washington, D.C.: GPO.

University of Wyoming Survey Research Center. 1989. 1982-1989 Monthly civilian labor force data for Park, Fremont and Hot Springs Counties. Laramie, WY: The University of Wyoming.

Wyoming Department of Administration and Fiscal Control. 1985. Wyoming population and employment forecast report. Cheyenne, WY: Wyoming Department of Administration and Fiscal Control. 
Wyoming Department of Labor Statistics. 1989. Wyoming Building Trades Index, 1988-1989. Cheyenne, WY: Wyoming Department of Labor Statistics.

Wyoming Department of Health. 1980-1987. Vital Statistics. Cheyenne, WY: Wyoming Department of Health.

Wyoming Economic Development and Stabilization Board. 1988. Wyoming: A Competitor for Jobs and Growth. Cheyenne: State of Wyoming.

-----. 1988. Wyoming Economic Development Plan. Cheyenne, WY: Wyoming Economic Development and Stabilization Board.

-.-.. 1989. FYI: Wyoming lifestyles. Cheyenne, WY: Wyoming Economic Development and Stabilization Board.

Wyoming Economic Development and Stabilization Board, Minerals Division. 1988. Wyoming directory of manufacturing and mining, 1987-1988. Cheyenne, WY: Wyoming Economic Development and Stabilization Board.

Wyoming Recreation Commission. 1985. Wyoming State Comprehensive Outdoor Recreation Plan Technical Report. Cheyenne: Wyoming Recreation Commission and the University of Wyoming.

\section{The Greater Yellowstone Area}

Baden, John A. and Donald Leal. 1990. The Yellowstone primer: Land and resource management in the Greater Yellowstone Ecosystem. San Francisco: Pacific Research Institute for Public Policy.

Chase, Alston. 1986. Playing God in Yellowstone: The destruction of America's first National Park. New York: The Atlantic Monthly Press.

Fletcher, Robert R. et al. 1988. Economic Analyses of Selected Industries Dependent upon the Bridger-Teton National Forest: With estimated impacts on eight local communities in four Wyoming counties. Laramie, WY: University of Wyoming Department of Agricultural Economics.

McNamee, Thomas. 1987. Nature first: Keeping our wild places and wild creatures wild. Boulder, CO: Roberts Rinehart, Inc. Publishers.

Reynolds, George. 1987. Promise or threat?: A study of "Greater Yellowstone ecosystem" management. Riverton, WY: Westerners concerned About Resources and Environment (WeCARE). 
USDA Forest Service. 1982. Demand for Forest outputs. Cody, WY: Shoshone National Forest.

USDA Forest Service. 1978. Beartooth Plateau Interim Land and Resource Management Plan (Shoshone, Custer, and Gallatin National Forests). Lakewood, CO: Rocky Mountain Regional Forester.

The Greater Yellowstone Coordinating Committee. 1989. The Greater Yellowstone post-fire assessment. Billings, MT: Greater Yellowstone Coordinating Committee.

\section{Human Resource Units}

Forest Statistics

Forest Outfitter List

Forest Special Use Permits List (database FLURFOR)

\section{a. Bighom Basin West HRU}

Mitchell, Thomas, F.H. Jackson, and O. Gonzales. 1988. Park County economic stability: One view of the future. Cody, WY: Shoshone National Forest

Wyoming Recreation Commission. 1987. Buffalo Bill State Park Master Plan. Cheyenne, WY: Wyoming State Recreation Commission

US Department of Interior, Water and Power Resources Service. 1980. Final EIS on the Modification of the Buffalo Bill Dam.

Husky Oil Co. 1982. Post-Closure Plan submitted to the EPA for Interim Status Hazardous Waste Management Facility.

Barnhart, Bill. 1981. The North Fork Trail: Guide and Pictoral History of Cody to Yellowstone. Wapiti, WY: Elkhorn Publishing.

Hatley, T. and K. Steward. 1980. The Sunlight Project: A Study of the Ecology and Politics of Land Management in Northwestern Wyoming. New Haven: Yale School of Forestry.

King, William. 1984. Environmental Assessment for Wyoming Project SCPF-0311 Yellowstone Park - Cody Road (US 14, 16, 20 Park County).

Nettles, D. 1971. Settlement and Growth of the Meeteetsee Area in NW Wyoming. Masters Thesis. Black Hills State College. 
Wyoming Highway Department. 1987. Powell Urban System Study: Major Street and Highway System Report.

Wyoming Department of Labor and Statistics. 1989. State of Wyoming Building Trades Index.

Nichols-Patrick, Lucille. 1968. The best little town by a dam site. Cheyenne: Flintlock Publishing Co.

State Economic Development and Stabilization Board. 1989. Community Profile Cody and Thermopolis, WY

\section{b. Beartooth HRU}

Glidden, Ralph. 1988. Exploring the Yellowstone high country: A History of the Cooke City area. Cooke City, MT: Cooke City Store.

USDA Forest Service. 1979. Clarks Fork of the Yellowstone Wild and Scenic River Study and Final EIS.

\section{c. Wind River $H R U$}

Response to the Bridger-Teton National Forest Land and Resource Management Plan - Town of Dubois

Ouderkirk, Eric. 1987. A selection of alternatives for the Town of Dubois, WY: Building a new home. Ann Arbor: the University of Michigan.

Dubois Economic Diversification Project. 1988.

Briefing Papers: 1. Technical Assistance to Dubois, WY, 2. Dubois Bighorn Sheep Center, 3. Analysis of the potential economic impacts on the Town of Dubois from the combined Bridger-Teton and Shoshone National Forest Plans 
e. Lander-Riverton HRU

Mather, Earl. 1989. Economic Development in Fremont County, WY: A Descriptive Analysis. EDA Grant Number 05-06-02338.

1989 Community Profiles - Riverton, Lander, Pavillion, Shoshoni, and Jeffrey City for the Governor's Economic Development tour of Fremont County, WY

4. Standards and Guidelines for Management

Whiskey Mountain Bighorn Sheep Comprehensive Plan

Shoshone Geophysical Investigations and Environmental Assessment

Big Horn Basin 208 Water Quality Management Plan

Memoranda of Understanding with other Agencies

Dunoir Special Management Unit Direction (P.L. 92-476)

Wyoming Wilderness Act of 1984

Guidelines for Management Involving Grizzly Bears in the Greater Yellowstone Area

Clarks Fork of the Yellowstone River Wild and Scenic River Study

Wyoming Oil and Hazardous Substances Pollution Contingency Plan

Shoshone National Forest Water Resource Monitoring Plan

\section{E. Technical Support Agencies}

1. Federal Agencies

a. Congressional Budget Office

b. Department of Agriculture

Economics and Statistics Service

Farmers Home Administration

Program Planning and Budget Office

c. Department of Commerce 

d. Economic Development Administration
e. Office of Management and Budget Statistical Policy Division
f. Department of Housing and Urban Development
g. Department of Labor
h. Domestic Council (Executive Office of the President)

2. Nongovernmental Organizations
a. Advisory Commission on Intergovernmental Relations
b. National Association of Towns and Townships
c. National Commission on Agricultural Land Use
d. National Rural Center
e. Urban Institute 


\section{B I B L I O G R A P H Y}

Anderson, Frederick R., D.R. Mandelkar, and A.D. Tarlock. 1984. Environmental protection: Law and policy. Boston: Little, Brown and Company.

Andrews, Frank M. and Stephen B. Withey. 1978. Social indicators of well-being: America's perceptions of life quality. New York: Plenum Press.

Arnstein, Sherry. 1969. A Ladder of citizen participation. Journal of the American Institute of Planners XXXC(July): 216-224.

Baden, John A. and Donald Leal. 1990. The Yellowstone primer: Land and resource management in the Greater Yellowstone Ecosystem. San Francisco: Pacific Research Institute for Public Policy.

Baltic, Tony J. et al. 1989. Review of critiques of the USDA Forest Service land management planning process. General Technical Report RM-170. Fort Collins, CO: USDA Forest Service, Rocky Mountain Forest and Range Experiment Station.

Benfield, F. Kaid. 1987. The administrative record and the range of alternatives in Forest Service planning: Applicable standards and inconsistent approaches. Environmental Law 17: 371-392.

Brubaker, Sterling. 1984. Rethinking the federal lands. Washington, D.C.: Resources for the Future.

Burch, William, Jr. 1984. Measuring the social impact of natural resource policies. Albuquerque: University of New Mexico Press.

Carhart, Arthur H. 1961. Planning for America's wildlands: A Handbook. Harrisburg, PA: The Telegraph Press.

Chase, Alston. 1986. Playing God in Yellowstone: The destruction of America's first National Park. New York: The Atlantic Monthly Press.

Culhane, Paul J. 1981. Public lands politics: Interest group influence on the Forest Service and the Bureau of Land Management. Baltimore: The Johns Hopkins University Press.

Dale, Duane. 1978. How to make citizen involvement work: Strategies for developing clout. Amherst, MA: University of Massachusetts Citizen Involvement Training Project. 
DeBonis, Jeff. 1989. From a man on the ground to the man on the top: Let's rethink how we manage the Forests. High Country News (Summer).

Dunn, William. 1981. Public policy analysis: An introduction. Englewood Cliffs, NJ: Prentice-Hall, Inc.

Edgerly, Len. 1983. Economic diversification: $A$ Wyoming alternative. Cody, WY: Wyoming Heritage Foundation.

Emrich, Wendy. 1981. Let us reason together: Environmental mediation and other new tools for resolving local disputes. Environmental Currents. Chadds Ford, PA: Brandywine Conservancy's Environmental Management Center.

Fletcher, Robert R. et al. 1988. Economic analyses of selected industries dependent upon the Bridger-Teton National Forest: With estimated impacts on eight local communities in four Wyoming counties. Laramie, WY: University of Wyoming Department of Agricultural Economics.

Forester, John. 1989. Planning in the face of power. Berkeley: University of California Press.

Frome, Michael. 1989. Conscience of a conservationist: Selected essays. Knoxville, TN: The University of Tennessee Press.

Gilford, D.M., G.L. Nelson, and L. Ingram. 1981. Rural America in passage: Statistics for policy. Washington, D.C.: National Academic Press.

Greiwe, Richard J. 1980. Procedures for characterizing and delineating a Human Resource Unit using cultural descriptors. Denver: Foundation for Urrban and Neighborhood Development, Inc.

1980. An introduction to social resource management. Denver, CO: FUND.

1980. Procedures for identifying and evaluating public issues, management concerns and management opportunities. Denver: Foundation for Urban and Neighborhood Development.

1982. Draft. Procedures for managing social impacts of resource decision-making. Denver: The Foundation for Urban and Neighborhod Development.

Innes (deNeufville), Judith. 1975. Social indicators and public policy: Interactive processes of design and application. New York: Russell Sage Foundation.

1981. Meeting human needs in the U.S.: A century of social policy and social indicators. Paper presented at a symposium on the Applicability of Indicators of Social Economic Change for Development Planning: Seoul, Korea.

BIB.-2 
------. 1990. Knowledge and public policy: The search for meaningful indicators. Galley. Transaction Publishers.

Institute for Participatory Management. 1986. Citizen participation handbook for public officials and other professionals serving the public. Laramie, WY: Institute for Participatory Management.

Jain, Ravinder K. and Bruce L. Hutchings. 1978. Environmental impact analysis: Emerging issues in planning. Urbana, IL: University of Illinois Press.

Johnson, Jeffrey P. 1986. Negotiating environmental and development disputes. Journal of Planning Literature 1, 4: 509-519.

Johnston, Denis and Michael Carley. 1981. Social Measurement and Social Indicators. Annals of the American Institute of Planners, 237-253.

Krutilla, John V. and John A. Haigh. 1978. An integrated approach to National Forest management. Environmental Law 8: 373-415.

Langton, Stuart. 1978. Citizen participation in America: Essays on state of the art. Lexington, MA: D.C. Heath and Company.

McAllister, Donald M. 1982. Evaluation in environmental planning: Assessing environmental, social, economic and political trade-offs. Cambridge, MA: Massachusetts Institute of Technology Press.

McEvoy, James and Thomas Dietz. 1977. Handbook for environmental planning: The social consequences of environmental change. New York: John Wiley and Sons.

McHarg, Ian. 1971. Design with nature. Garden City, NY: Doubleday and Company, Inc.

McNamee, Thomas. 1987. Nature first: Keeping our wild places and wild creatures wild. Boulder, CO: Roberts Rinehart, Inc. Publishers.

Mitchell, Thomas. 1988. General analysis and project identification in National Forest planning: $A$ discussion. Cody, WY: USDA Forest Service.

Mohai, Paul. 1987. Rational decisionmaking in the planning process: Some empirical evidence from RARE II. Environmental Law 17: 507-529.

Moore, M.A.D., P.J. Case, and D.A. Jameson. 1982. Principles of land and resource management planning. Lakewood, CO: Eisenhower Consortium for Western Environmental Forestry Research, USDA Forest Service Rocky Mountain Region, and USDA Forest Service - Land Management Planning Office.

BIB.-3 
Mulhern, Timothy P. 1978. The National Forest Management Act of 1976: A Critical examination. Boston College Environmental Affairs Law Review 7, 1: 99-126.

Nelkin, Dorothy. 1982. Public participation in environmental planning in the U.S. In Integrated physical, socio-economic and environmental planning. Yusuf J. Ahmad and Frank G. Muller, eds. Dublin, Ireland: United Nations Environment Programme and Tycooly International Publishers Limited.

Organization for Economic Cooperation and Development. 1977. Basic disaggregation of main social indicators. Paris: Organization for Economic Co-operation and Development.

Osborne, John C. 1976. Citizen Participation in the Planning Process: A QuantitativeDescriptive Analysis. Kingston, RI: CPAD Master of Community Planning Thesis.

Palmer, Charles and Joanne Tremaine. 1982. Draft: A proposed role of social analysis in National Forest planning and decisionmaking. Lakewood, CO: Rocky Mountain Regional Forester's Office.

Plessas, Demetrium and Ricca Fien. 1972. An evaluation of social indicators. Journal of the American Institute of Planners, 43-51.

Rein, M. and D. Schon. 1977. Problem setting in policy research. In Using social research in public policy making. Lexington, MA: D.C. Heath and Company.

Reynolds, George. 1987. Promise or threat?: A study of "Greater Yellowstone ecosystem" management. Riverton, WY: Westerners Concerned About Resources and Environment (WeCARE).

Rossi, Robert and Kevin Gilmartin. 1980. Handbook of social indicators. New York: Garland STPM Press.

Schneider, M. 1976. The Quality of life and social indicator research. Public Administration Review

Schallau, Con H. 1987. The commitment to community stability: A policy or shibboleth? Environmental Law 17: 429-452.

Schweitzer, Dennis L. et al. 1984. Is planning worth it? Journal of Forestry 82: 404-407.

Shannon, Margaret A. 1986. Citizen participation in land management planning: The formation of a social contract. Washington, D.C.: USDA Office of the General Counsel, Natural Resources Division.

Soderstrom, Edward J. 1981. Social Impact Assessment: Experimental methods and approaches. New York: Praeger Press.

BIB. -4 
SRI International. 1985. Building a stronger Wyoming: Opportunities in a troubled economy. Cheyenne: Wyoming EDSB.

Taylor, Serge. 1984. Making bureaucracies think: The environmental Impact Statement strategy of administrative reform. Stanford, CA: Stanford University Press.

The Greater Yellowstone Coordinating Committee. 1989. The Greater Yellowstone postfire assessment. Billings, MT: Greater Yellowstone Coordinating Committee.

The Wilderness Society. 1983. National Forest planning: $A$ Conservationist's guide. Washington, D.C.: The Wilderness Society.

Tremaine, Joanne. 1981. A framework for socially responsive management and social impact assessments in the Rocky Mountain Region. Lakewood, CO: Rocky Mountain Regional Forester's Office.

United Nations Department of International Economic and Social Affairs. 1989. Handbook on social indicators. New York: United Nations.

U.S. Department of Commerce. 1988. City and County Data Book. Washington, D.C.: GPO.

U.S. Department of Commerce. 1986. County Business Patterns, Wyoming. Washington, D.C.: GPO.

U.S. Department of Commerce. 1989. Statistical Abstract of the U.S. Washington, D.C.: GPO.

U.S. Department of Agriculture (UDSA) Forest Service, Rocky Mountain Region. 1989. Notice of Intent: Exemption of fire recovery projects from appeal. Federal Register (May 31) 54, 103: 23239.

USDA Forest Service. 1978. Beartooth Plateau Interim Land and Resource Management Plan (Shoshone, Custer, and Gallatin National Forests). Lakewood, CO: Rocky Mountain Regional Forester.

USDA Forest Service. 1978 (1985 and 1988 amendments). Forest Service Handbook CEQ NEPA Regulations: Regulations for the Procedural Provisions of the National Environmental Policy Act. Washington, D.C.: GPO.

USDA Forest Service. 1982. Demand for Forest outputs. Cody, WY: Shoshone National Forest.

USDA Forest Service. 1986. Shoshone National Forest Land and Resource Management Plan and Final Environmental Impact Statement. Cody, WY: USDA Forest Service. 
--.--. 1988. Wyoming Economic Development Plan. Cheyenne, WY: Wyoming Economic Development and Stabilization Board.

------- 1989. FYI: Wyoming lifestyles. Cheyenne, WY: Wyoming Economic Development and Stabilization Board.

Wyoming Economic Development and Stabilization Board, Minerals Division. 1988. Wyoming directory of manufacturing and mining, 1987-1988. Cheyenne, WY: Wyoming Economic Development and Stabilization Board.

Wyoming Recreation Commission. 1985. Wyoming State Comprehensive Outdoor Recreation Plan Technical Report. Cheyenne: Wyoming Recreation Commission and the University of Wyoming. 